Boise State University

ScholarWorks

Geosciences Faculty Publications and

Presentations

Department of Geosciences

$2-2018$

\title{
One Diamictite and Two Rifts: Stratigraphy and Geochronology of the Gataga Mountain of Northern British Columbia
}

Athena Eyster

Harvard University

Filippo Ferri

British Columbia Ministry of Natural Gas Development

Mark D. Schmitz

Boise State University

Francis A. Macdonald

Harvard University

This document was originally published in the American Journal of Science by HighWire Press. Copyright restrictions may apply. doi: 10.2475/02.2018.1 


\title{
American Journal of Science
}

\author{
FEBRUARY 2018
}

\section{ONE DIAMICTITE AND TWO RIFTS: STRATIGRAPHY AND GEOCHRONOLOGY OF THE GATAGA MOUNTAIN OF NORTHERN BRITISH COLUMBIA}

\author{
ATHENA EYSTER $*,{ }^{\S}$, , FILIPPO FERRI**, MARK D. SCHMITZ***, and \\ FRANCIS A. MACDONALD*
}

\begin{abstract}
Neoproterozoic glacial diamictites and rift-related volcanics are preserved throughout the North American Cordillera, yet the nature and timing of both glaciation and rifting are poorly constrained. New geochronological, geochemical, and stratigraphic data from the Cryogenian Gataga volcanics and bounding units at Gataga Mountain, in the Kechika Trough of northern British Columbia, better constrain the age of these rift-related volcanics and suggest that they erupted during glaciation. At Gataga Mountain, three informal sequences are exposed; a basal quartzite, the Gataga volcanics, and an overlying mixed carbonate-siliciclastic succession. The basal quartzite is dominated by cross-bedded sandstone with an intertidal facies assemblage including bidirectional cross-stratification and mud-cracks, indicative of non-glacial deposition. The overlying Gataga volcanics are over one kilometer thick, comprising both mafic and felsic units, with volcaniclastic breccia and interbedded sedimentary units including iron formation and matrix-supported diamictite with exotic clasts. Magmatic ages in the upper Gataga volcanics span 696.2 \pm 0.2 to $690.1 \pm 0.2 \mathrm{Ma}$, and detrital zircon from the underlying non-glacial quartzite provide a maximum age constraint on the onset of glaciation $<735.8 \pm 0.6 \mathrm{Ma}$. We interpret interfingering beds of matrix-supported diamictite with exotic clasts within the Gataga volcanics to record sub-ice shelf sedimentation and volcanism during the Sturtian Glaciation. Although volcanic facies are consistent with eruption in a sub-ice to sub-aqueous (below ice shelf) environment, we acknowledge the difficulty of distinguishing sub-glacial from sub-aqueous explosive volcanic facies. Overlying the Gataga volcanics, a mixed carbonate-siliciclastic succession contains minor basalt flows that are geochemically distinct from the underlying volcanic rocks. Based on chemostratigraphic and lithostratigraphic similarities, we suggest that this sequence is correlative with Ediacaran strata to the north. Together, we suggest that the stratigraphy and geochemical signature of volcanic rocks at Gataga Mountain records two episodes of Neoproterozoic extensionrelated sedimentation and volcanism, the first indicated by the Cryogenian Gataga volcanics and interbedded sedimentary strata and the second by the overlying Ediacaran carbonate-siliciclastic succession with interfingering basalt.
\end{abstract}

Keywords: Gataga volcanics, Windermere Supergroup, Neoproterozoic Laurentian rifting, Sturtian Glaciation

\footnotetext{
* Department of Earth and Planetary Sciences, Harvard University, 20 Oxford Street, Cambridge, Massachusetts 02138, USA

** British Columbia Ministry of Natural Gas Development, PO Box 9323 Stn Prov Govt, Victoria, British Columbia, V8W 9N3, CANADA USA

*** Department of Geosciences, Boise State University, 1910 University Drive, Boise, Idaho 83725-1535,

$\$$ Present address: Department of Earth, Atmospheric and Planetary Sciences, Massachusetts Institute of Technology, 77 Massachusetts Ave, Cambridge, Massachusetts 02139, USA

${ }^{+}$Corresponding author: aeyster@mit.edu
} 
INTRODUCTION

During the Neoproterozoic, the supercontinent Rodinia amalgamated and broke apart (Li and others, 2008), and there were two long-lasting Cryogenian Snowball Earth glaciations (Kirschvink, 1992; Hoffman and Schrag, 2002; Rooney and others, 2015). Laurentia is central to unraveling the tectonic history of Rodinia because it was surrounded by Neoproterozoic to Cambrian rifted passive margins (Hoffman, 1991), and reconstructions place it at the core of Rodinia ( $\mathrm{Li}$ and others, 2008, 2013; Evans, 2013). Previous studies have linked the low-latitude break-up of Rodinia with the onset of Cryogenian glaciation (for example Hoffman and Schrag, 2002; Godderis and others, 2003; Cox and others, 2016); however, the age and kinematics of Rodinia's fragmentation, and the relationship to environmental change remain poorly constrained.

The rift history of the western margin of Laurentia is recorded in strata exposed in the U.S. and Canadian Cordillera and is commonly represented by three main stratigraphic ensembles. The first is found in the narrow fault bounded extensional Chuar-Uinta Mountains-Pahrump (ChUMP) basins of the U.S., which includes the Chuar Group exposed in Arizona, the Pahrump Group of California, and the Uinta Mountains Group and the Big Cottonwood Formation in Utah (Karlstrom and others, 2000; Dehler and others, 2010; Smith and others, 2016), and the Mt. Harper (Strauss and others, 2015) and Coates Lake (Jefferson and Parrish, 1989) groups of the Yukon and Northwest Territories, Canada. These basins formed between $c a .775$ and $717 \mathrm{Ma}$ (Macdonald and others, 2010a; Milton and others, 2014) and are filled with mixed carbonate-siliciclastic sequences that share correlative fossil assemblages and carbon isotope chemostratigraphic profiles (Porter and Knoll, 2000; Dehler and others, 2010; Macdonald and others, 2013a; Strauss and others, 2014a; Strauss and others, 2015; Smith and others, 2016). Subsidence in these latest Tonian basins has been attributed to early rifting and subsidence (Dehler and others, 2010), initial development of intracratonic basins (Yonkee and others, 2014), oblique transtension (Strauss and others, 2015), or distinct and separate tectonothermal events (Smith and others, 2016). The second ensemble encompasses Cryogenian to early Ediacaran siliciclastic and volcanic successions commonly interbedded with glacial diamictite and carbonate that have been interpreted as representing rifting across the entire margin (Stewart, 1972; Eisbacher, 1981, 1985; Jefferson and Parish, 1989). Finally, there is a widespread succession of Ediacaran carbonate and siliciclastic strata that are widely interpreted to be related to subsidence and the initiation of passive margin sedimentation (Ross, 1991; Ross and others, 1995; and Dalrymple and Narbonne, 1996), or to a separate, later rifting event (Colpron and others, 2002; Macdonald and others, 2013b).

Previous studies have marked the onset of Neoproterozoic rifting in the Cordillera with the identification of alkalic igneous rocks and coarse sedimentation (Gabrielse, 1972; Stewart, 1972; Christie-Blick and Levy, 1989; Aitken, 1993; Link and others, 1993; Lund and others, 2003); however, because there are multiple magmatic events over a period of more than 200 million years, it is unclear if all of the magmatism can be attributed to one episode of rifting. Sills, dikes and basalts associated with the Gunbarrel Large Igneous Province (LIP) have been dated at $c a .775$ Ma (Harlan and others, 2003; Milton and others, 2014), and have been suggested to mark rifting on the western margin of Laurentia (for example Jefferson and Parrish, 1989). Additionally, basal Windermere volcanics have been dated at 717.43 \pm 0.14 Ma with U-Pb chemical abrasion-isotope dilution-thermal ionization mass spectrometry (CA-ID-TIMS) on zircon in the Yukon, and at $685.5 \pm 0.4 \mathrm{Ma}$ (zircon U-Pb CA-ID-TIMS) in Idaho (Macdonald and others, 2010a; Keeley and others, 2013). Finally, there are younger magmatic events, recorded by $c a$. 665 to $650 \mathrm{Ma}$ alkaline plutons in central Idaho 
(Lund and others, 2010), and 569.6 \pm 5.3 Ma magmatism (bulk zircon U-Pb ID-TIMS) from the Hamill Group in southeastern British Columbia (Colpron and others, 2002).

An additional complication is that subsidence curves of Paleozoic strata on the western margin of Laurentia (Armin and Mayer, 1983; Bond and Kominz, 1984; Bond and others, 1985) suggest that the rift-drift transition and development of the passive margin did not occur until the $c a$. 541 Ma Precambrian-Cambrian boundary ${ }^{1}$. Thus, the older magmatism is too old to be tied to the thermal subsidence and development of the Paleozoic passive margin. This discrepancy in ages could suggest multiple rift events or protracted rifting (Prave, 1999; Colpron and others, 2002; Macdonald and others, 2013b).

The geochronological data on rift-related volcanic rocks and the later rift-drift transition at the Precambrian-Cambrian boundary is also at odds with paleogeographic models that rely on paleomagnetic data, which depict crustal blocks that have successfully rifted off the western Laurentia by $750 \mathrm{Ma}$ (for example, Meert and Torsvik, 2003; Cawood, 2005; Li and others, 2008). However, it is still not agreed upon what continent(s) rifted away from Laurentia's western margin, with candidates including Antarctica, Australia, North China, South China, Tarim, and West Africa (Sears and Price, 1978; Moores, 1991; Hoffman, 1991; Dalziel, 1997; Sears and Price, 2003; Pisarevsky and others, 2003; Li and others, 2008; Evans, 2009; Fu and others, 2015). Considering such uncertainty in the paleomagnetic and paleogeographic models, it is also possible that the western margin experienced multiple rift events that involved the rifting of ribbon continents or continental fragments, rather than a separation of a large craton.

Along with uncertainties and inconsistencies related to the timing of Rodinian break-up, and the identity of what rifted off, the geometry and kinematics of rifting is also poorly constrained. It has been proposed that the current zigzag-geometry of the Neoproterozoic to Cambrian margin is related to pure-shear extension with opposing upper and lower plate segments (Wernicke, 1985; Lister and others, 1986), with the lower plate experiencing extreme thinning of continental crust and subsidence across a broad continental shelf, while the upper plate is marked by limited thinning of the crust and narrow continental shelf margins (Lund and others, 2010). In this model, the broad basins of the Selwyn Basin and Mackenzie Platform in northern Canada formed on a northwest-striking lower-plate extensional margin, while in British Columbia, the narrow Kechika Trough and the MacDonald Platform formed on a northweststriking upper-plate margin (Ross, 1991; Cecile and others, 1997), with the northeaststriking Liard line representing a transfer zone that separates opposite-polarity segments (Cecile and others, 1997; Lund and others, 2003; Lund, 2008). However, it is unclear how this model would relate to protracted rifting, translation along the margin, or changing plate geometries and plate directions. Particularly, local evidence for transpression (for example Eisbacher, 1981) and vertical axis block rotations (Eyster and others, 2017) suggest a component of oblique motion along the margin.

In addition to the complex rift history preserved in the Windermere Supergroup, these strata also preserve evidence of Cryogenian glaciations (for example, Gabrielse, 1972; Stewart, 1972; Eisbacher, 1978; Crittenden and others, 1983; Christie-Blick and Levy, 1989; Aitken, 1991; Link and others, 1994; Miller, 1994; Prave, 1999; Lund and others, 2003; Macdonald and others, 2010a). Although Neoproterozoic glacial successions are recognized worldwide, the nature, timing, and duration of glacial episodes has remained controversial (Spence and others, 2016). Nonetheless, paleomagnetic data suggests that some of the Cryogenian glacial diamictites were deposited at low

\footnotetext{
${ }^{1}$ The rift-drift transition reported in these manuscripts is older because at the time the age of the Precambrian-Cambrian boundary was thought to be $c a .575 \mathrm{Ma}$.
} 
latitudes, consistent with the Snowball Earth hypothesis (Kirschvink, 1992; Evans and Raub, 2011; Eyster and others, 2017). Moreover, recent geochronology confirms that there were two discrete, long-lived Cryogenian glaciations, the Sturtian and the Marinoan (Rooney and others, 2015; Prave and others, 2016). The onset of the Sturtian glaciation is dated by chemical abrasion isotope dilution thermal ionization mass spectrometry (CA-ID-TIMS) U-Pb zircon age of 716.47 $\pm 0.24 \mathrm{Ma}$ from diamictites of the Mount Harper Group in Yukon, Canada (Macdonald and others, 2010a). The end of the glaciation is marked by a postglacial Re-Os date of $662.4 \pm 3.9 \mathrm{Ma}$ on the basal Twitya Formation in Northwest Territories, Canada (Rooney and others, 2014). The age of the Marinoan glacial epoch is bracketed between $655 \mathrm{Ma}$ (Zhang and others, 2008) and $635 \mathrm{Ma}$ (Condon and others, 2005; Calver and others, 2013; Rooney and others, 2015), with the later marking the age of the Marinoan cap carbonate. These data, along with the most robust geochronological constraints globally, suggest a $>55$ million year duration for the Sturtian glaciation (Rooney and others, 2014, 2015), and > 5 million year duration for the Marinoan glaciation (Prave and others, 2016). Although, some suggest that there were multiple glaciations between $c a$. 716 to $660 \mathrm{Ma}$, with a possible interglacial period (Le Heron, 2011; Keeley and others, 2013), only one Sturtian cap carbonate has been identified. Thus, during much of the interval that the western margin of Laurentia was experiencing rifting, it appears that equatorial latitudes may have been entombed by Cryogenian glaciation.

To further explore the relationships between rifting and glaciation on the western margin of Laurentia, we revisited the Gataga Mountain area in northern British Columbia. A rhyolite within the Gataga volcanics was previously dated (five bulk zircon fractions ID-TIMS upper intercept age) at 688.9 +9.5/-6.2 Ma (U-Pb) and 689.1 \pm 4.6 $\mathrm{Ma}(\mathrm{Pb}-\mathrm{Pb})$ (Ferri and others, 1999). This age has been cited as a constraint on rift-related Windermere magmatism (Colpron and others, 2002; Lund, 2008; Keeley and others, 2013). In addition to the volcanic rocks exposed at Gataga Mountain, Ferri and others (1999) documented carbonate, siliciclastic rocks and additional basalt flows (Upper Gataga volcanics) about $7 \mathrm{~km}$ to the north. The preferred interpretation of Ferri and others (1999) was that these upper basalt flows were due to a separate, younger volcanic extensional event and that there was an unconformity between the two volcanic packages; however, it was also acknowledged that it is possible that the volcanics were of a similar age, and the observed relationships had been complicated by faulting (Ferri and others, 1999). As the Gataga volcanics were interpreted to conformably overlie carbonate and quartzite, and underlie an additional Neoproterozoic to Cambrian sedimentary succession with interbedded volcanic rocks, both without evidence for glaciation (Ferri and others, 1999), this date presents a challenge to age models for an extended Sturtian glaciation, and also potentially provides an important constraint on rifting. To place the Neoproterozoic volcano-sedimentary sequence into a tighter temporal and regional stratigraphic framework, we report new geological mapping, measured stratigraphic sections, geochronology, and carbon isotope chemostratigraphy. These data are then integrated with Neoproterozoic tectonic and climate records across the western margin of Laurentia.

METHODS

\section{Mapping and Stratigraphy}

We report new data from two main localities, Gataga Mountain itself and a ridge 7 $\mathrm{km}$ to the northwest that we informally refer to as Matulka Creek Ridge (fig. 1). Our updated mapping focused on three informal Precambrian units, the Frog quartzite, the Gataga volcanics, and the Matulka group. The Gataga volcanics were further subdivided into six mappable units, members A-E and an intrusive unit. These units are exposed in north plunging folds, bounded to the east by a series of thrust faults. 


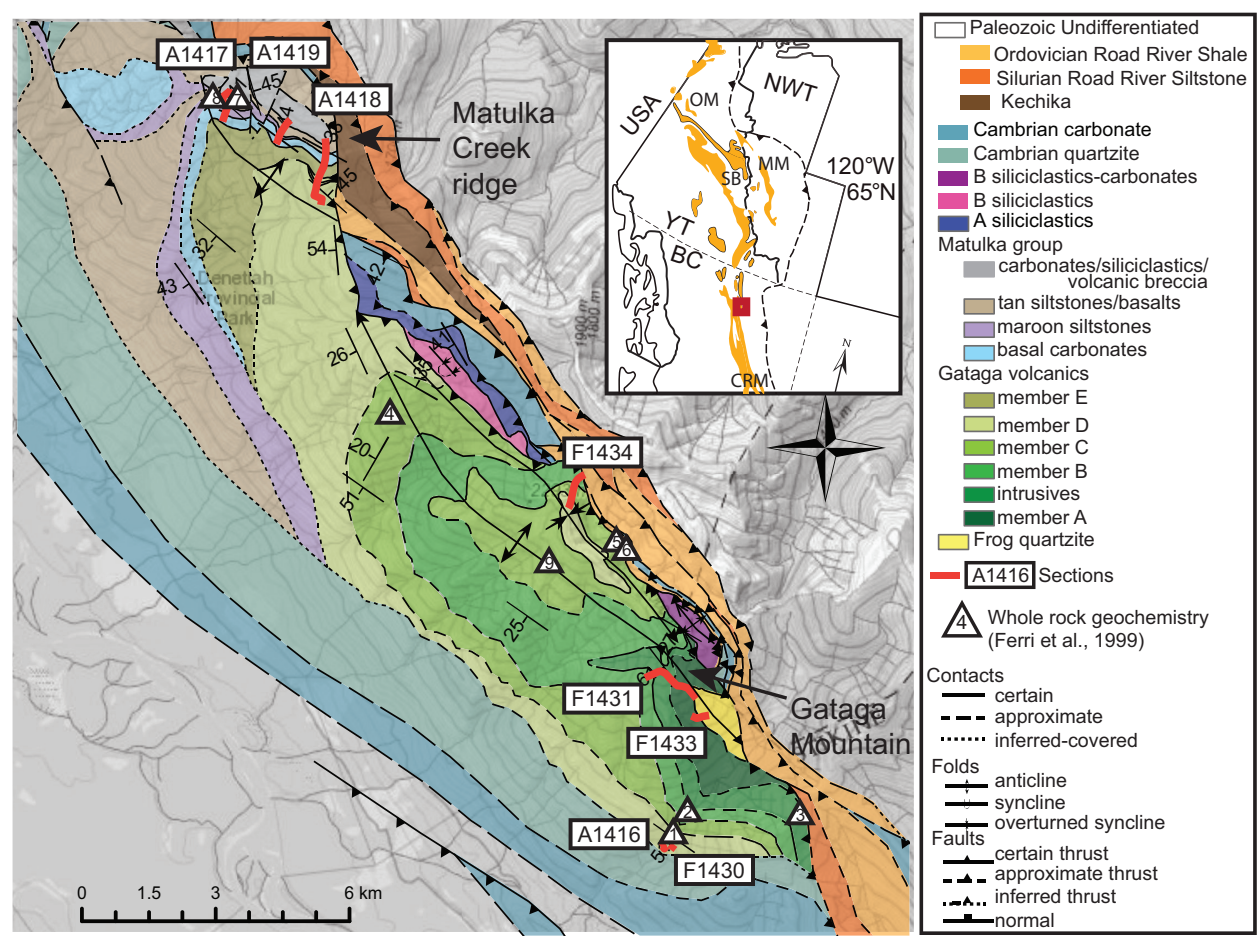

Fig. 1. Geological map of the Gataga Mountain area with sample and section locations indicated. Inset map shows distribution of Neoproterozoic Windermere strata (after Wheeler and McFeely, 1991), the red box highlights the Gataga mountain area and locations of the Ogilvie Mountains (OM), the Mackenzie Mountains (MM), the Selwyn Basin (SB), and the Central Rocky Mountains (CRM) are shown.

During the course of geological mapping, suitable sections were identified for measuring the stratigraphy (fig. 1), and these sections were staffed and described using standard lithostratigraphic terminology (fig. 2). All geochronological and geochemical samples were collected from these measured stratigraphic sections.

\section{Geochronology Sample Preparation}

Fourteen samples were collected for geochronology (fig. 2). Mineral separation was performed at Harvard University, using standard density and magnetic isolation techniques. The entire zircon separate was placed in a muffle furnace at $900{ }^{\circ} \mathrm{C}$ for 60 hours in quartz beakers to anneal minor radiation damage; annealing enhances Cathodoluminescence (CL) emission (Nasdala and others, 2002), promotes more reproducible inter-element fractionation during laser ablation inductively coupled plasma mass spectrometry (LA-ICPMS) (Allen and Campbell, 2012), and prepares the crystals for subsequent chemical abrasion (Mattinson, 2005). Following annealing, individual grains were hand-picked and mounted in epoxy, polished and imaged by cathodoluminescence (CL) on a JEOL T-300 scanning electron microscope fitted with a GATAN MiniCL detector. From these compiled images, grains with consistent and dominant CL patterns were selected for further isotopic analysis.

\section{U-Pb LA-ICP-MS Geochronology and Zircon Geochemistry}

Microbeam analysis of zircon was conducted using a ThermoElectron X-series II quadrupole inductively coupled plasma mass spectrometer (ICPMS) and New Wave 


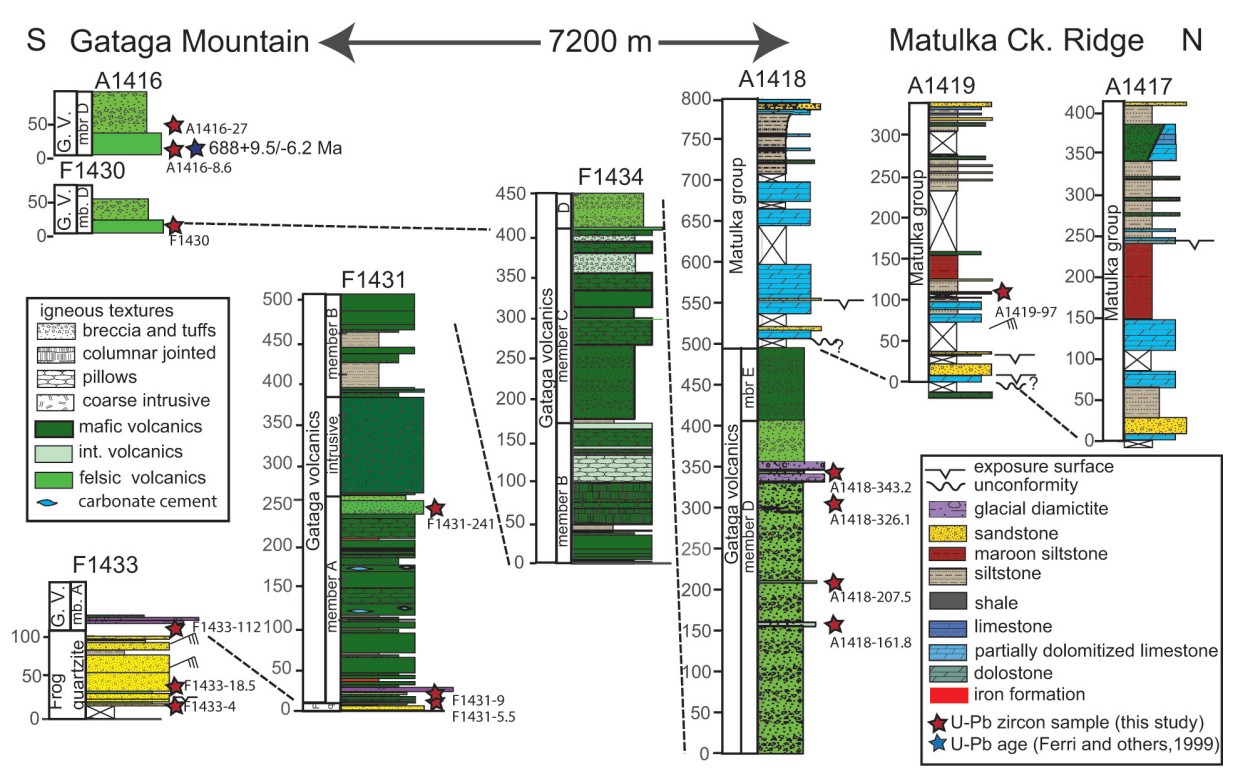

Fig. 2. Measured stratigraphic sections from Gataga Mountain in the south to Matulka Creek ridge in the north. Stratigraphy scale is in meters and the heights of geochronology samples are indicated as well as the location of the previously sampled age from Ferri and others (1999).

Research UP-213 Nd:YAG UV (213nm) laser ablation system to obtain U-Pb ages and high field strength element (HFSE) and rare earth element (REE) data. For this, a laser diameter of $25 \mu \mathrm{m}$, fluence of $5 \mathrm{~J} / \mathrm{cm}^{2}$, and continuous pulse repetition of $10 \mathrm{~Hz}$ was used in a 30 second spot acquisition. Two to four U-Pb calibration (Plesovice) and quality control (Zirconia, Seiland) standards were measured every 10 samples, as well as NIST 610 and 612 glass standards for elemental concentration calibration. For the detrital samples, reported ages for zircon samples younger than $1000 \mathrm{Ma}$ reflect the ${ }^{206} \mathrm{~Pb} /{ }^{238} \mathrm{U}$ date, and the ${ }^{207} \mathrm{~Pb} /{ }^{206} \mathrm{~Pb}$ date for zircons older than $1000 \mathrm{Ma}$. Ages with $> \pm 10$ percent discordance were eliminated from subsequent detrital zircon analysis. The plots of relative age probability were made using Microsoft Excel "Isoplot" developed by the Berkeley Geochronology Center and include $2 \sigma$ errors. The LA-ICP-MS work was followed by CA-ID-TIMS work on selected grains. Selected grains were those that were youngest for the detrital or mixed detrital-magmatic samples, and those that appeared representative of a single magmatic population for the volcanic samples.

\section{U-Pb ID-TIMS Geochronology}

U-Pb geochronology methods for ID-TIMS follow those previously published by Davydov and others (2010) and Schmitz and Davydov (2012). Zircon crystals were subjected to a modified version of the chemical abrasion method of Mattinson (2005), whereby single crystal fragments plucked from grain mounts were individually abraded in a single step with concentrated HF at $180{ }^{\circ} \mathrm{C}$ for 12 hours. All analyses were undertaken on crystals previously mounted, polished and imaged by cathodoluminescence (CL), and selected on the basis of zoning patterns. U-Pb dates and uncertainties for each analysis were calculated using the algorithms of Schmitz and Schoene (2007) and the U decay constants of Jaffey and others (1971). Uncertainties are based upon nonsystematic analytical errors, including counting statistics, instrumental fractionation, 
tracer subtraction, and blank subtraction. These error estimates should be considered when comparing our ${ }^{206} \mathrm{~Pb} /{ }^{238} \mathrm{U}$ dates with those from other laboratories that used tracer solutions calibrated against the EARTHTIME gravimetric standards. When comparing our dates with those derived from other decay schemes (for example, $\left.{ }^{40} \mathrm{Ar} /{ }^{39} \mathrm{Ar},{ }^{187} \mathrm{Re}^{187} \mathrm{Os}\right)$, the uncertainties in tracer calibration $(0.03 \%$; Condon and others, 2015; McLean and others, 2015) and U decay constants $(0.108 \%$; Jaffey and others, 1971) should be added to the internal error in quadrature. Quoted errors for calculated weighted means are thus of the form $\pm \mathrm{X}(\mathrm{Y})[\mathrm{Z}]$, where $\mathrm{X}$ is solely analytical uncertainty, $\mathrm{Y}$ is the combined analytical and tracer uncertainty, and $\mathrm{Z}$ is the combined analytical, tracer and ${ }^{238} \mathrm{U}$ decay constant uncertainty.

\section{Carbon Isotope Chemostratigraphy}

Fist- to golf ball-sized samples were collected at 1 to $5 \mathrm{~m}$ resolution in measured stratigraphic sections for carbonate carbon $\left(\delta^{13} \mathrm{C}_{\mathrm{carb}}\right)$ and oxygen $\left(\delta^{18} \mathrm{O}_{\text {carb }}\right)$ isotope chemostratigraphy. At Harvard University, the samples were cut perpendicular to laminations and approximately $5 \mathrm{mg}$ of powder was produced by drilling, taking care to avoid veins and fractures. The $\delta^{13} \mathrm{C}_{\text {carb }}$ and $\delta^{18} \mathrm{O}_{\text {carb }}$ data was obtained on a VG Optima dual inlet isotope ratio mass spectrometer coupled with a VG Isocarb preparation device (Micromass, Milford, Massachusetts) in the Laboratory for Geochemical Oceanography at Harvard University. Approximately $1 \mathrm{mg}$ of sample powder was reacted in a common, purified phosphoric acid $\left(\mathrm{H}_{3} \mathrm{PO}_{4}\right)$ bath at $90{ }^{\circ} \mathrm{C}$. The evolved $\mathrm{CO}_{2}$ was collected cryogenically and analyzed using an in-house reference gas. Calibration to (Vienna-Pee-Dee Belemnite) VPDB was done using the Cararra marble standard (CM2). Total analytical errors $(1 \sigma)$ were better than \pm 0.1 permil for both $\delta^{13}$ $\mathrm{C}_{\mathrm{carb}}$ and $\delta^{18} \mathrm{O}_{\text {carb }}$ based on repeat analysis of standards and samples. The $\delta^{13} \mathrm{C}_{\mathrm{carb}}$ and $\delta^{18} \mathrm{O}_{\text {carb }}$ isotopic results are reported in permil notation of ${ }^{13} \mathrm{C} /{ }^{12} \mathrm{C}$ and ${ }^{18} \mathrm{O} /{ }^{16} \mathrm{O}$ relative to the standard VPDB.

RESULTS

\section{Metamorphism and Structure}

It must be noted that throughout the Gataga volcanics folding and pervasive foliation obscures paleo-topographic and textural features. At its western boundary, the Gataga Mountain area follows the Northern Rocky Mountain Trench fault zone, an area of deformation that delineates the boundary between displaced continental rocks and ancestral North American strata. Therefore, it is unremarkable that the Gataga Mountain rocks have been substantially faulted and display metamorphism and cleavage. The metamorphism and cleavage in the area is consistent with previous documentation by Ferri and others (1999). Metamorphic mineral assemblages in mafic volcanics were of chlorite, calcite, albite(?), epidote, white mica, pumpellyite, stilpnomelane, while pelitic rocks contained white mica (illite or phengite), chlorite, quartz, calcite and dolomite. Throughout the area, pervasive, slaty cleavage is present within argillaceous units. While cleavage was rare in clean quartzite and carbonate, there was displayed a widely spaced fracture cleavage, while a pressure-solution cleavage was sometimes seen in argillaceous limestones (Ferri and others, 1999). In addition, although primary textures could be observed in some carbonate outcrops, stylolites were also common and the rocks were frequently recrystallized, dolomitized and silicified. Cleavage and alteration tended to be more pervasive nearing thrust faults. These small-scale features were related to the intense eastward compression during the late Mesozoic that produced the dominant structural fabrics and the interrelated folding and thrusting, with thrusts commonly carrying detached anticlines (Ferri and others, 1999). Despite this deformation, primary textures were identifiable in all units. 

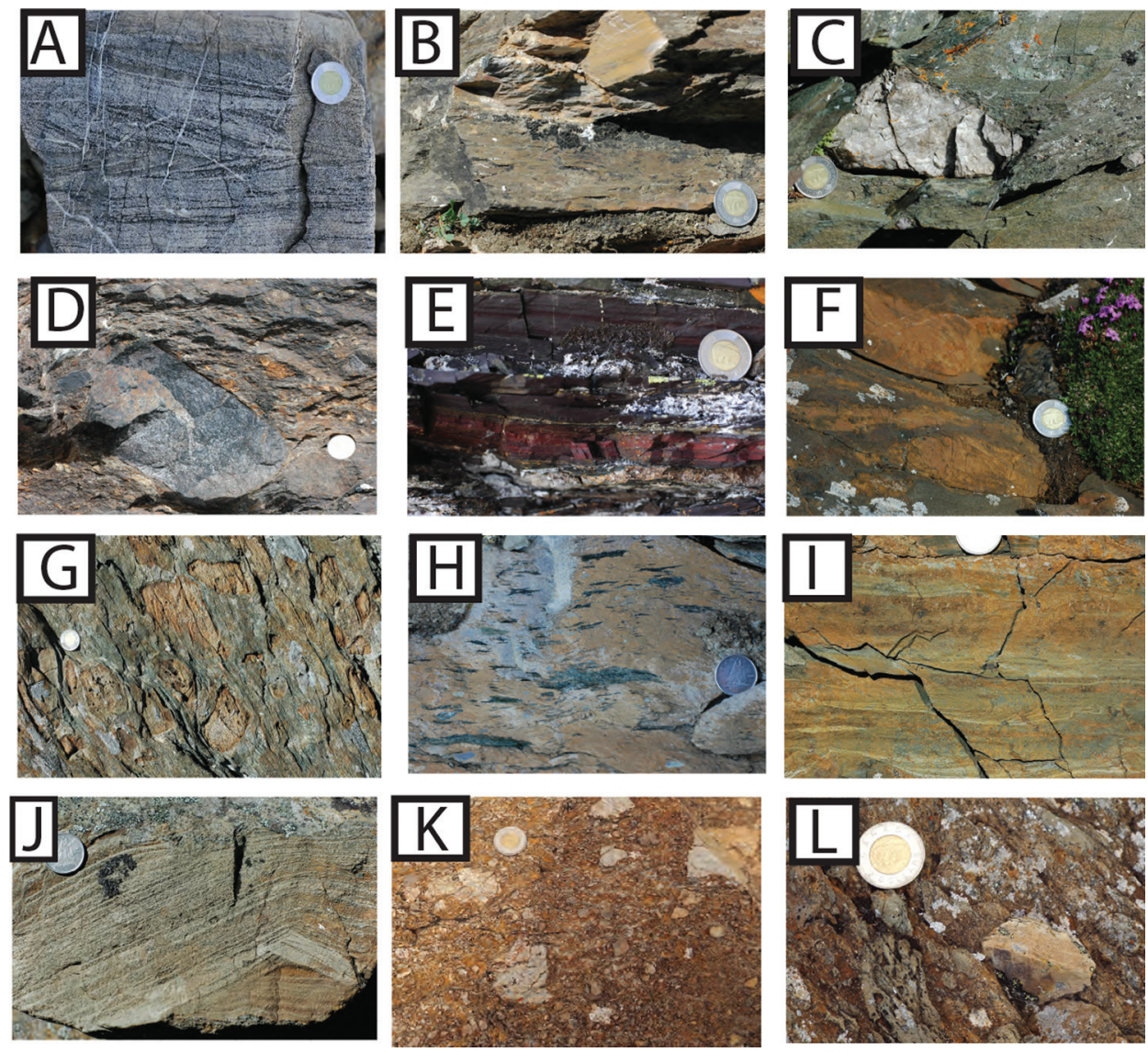

Fig. 3. Field photos. Frog quartzite: (A) F1433 bidirectional crossbeds. Gataga volcanics member A: (B) F1431-9 interbedded lithic tuff, (C) F1431 diamictite with a quartzite clast in a wacke matrix, (D) F1433-116 diamictite with a quartzite clast in a fine sand-sized pink lithic matrix, (E) F1431 iron formation. Gataga volcanics member C: (F) F1431 carbonate cements in volcanics, (G) F1434-340 block and ash flow, (H) F1434 flattened volcanic clasts in a fine volcanic matrix, (I) F1434-310 festoon cross-bedding in volcanics, (J) F1434-320 antidune cross-bedding in a clast. Gataga volcanics member D: (K) A1418 felsic volcanic breccia with carbonate clasts. (L) A1418 laminated siltstone clast in a felsic volcaniclastic breccia. Canadian loonie (28mm diameter), toonie (26.5mm diameter), or a hammer for scale.

\section{Stratigraphy}

The oldest map unit, which we refer to as the Frog quartzite, after nearby Frog River, is exposed in the core of the Gataga anticline. This unit is up to several hundred meters thick and dominated by white-cream fresh and beige weathering massive mature quartzite with meter-scale planar cross-beds and bidirectional cross-stratification (fig. 3A). Minor interbeds of yellow- to green-brown siltstone, lithic tuffs and fine-grained sandstone are present and mud cracks were observed in scree.

Above a sharp surface, the Frog quartzite is succeeded by the Gataga volcanics, which were previously subdivided into two packages: a unit of alkalic mafic to intermediate flows and volcaniclastic rocks, followed by a sequence of felsic volcanics and volcaniclastic rocks found only along the southwestern slopes of Gataga Mountain (Ferri and others, 1999). Our new work subdivides the Gataga volcanics into six mappable units, members A-E and an intrusive member, and observes that the felsic 
volcanics and volcaniclastic rocks outcrop rather expansively to the north of Gataga Mountain.

Member A is approximately $350 \mathrm{~m}$ thick and is dominated by green to black weathering basalt flows with minor inter-tonguing sedimentary strata. Basalt flows range in thickness from tens of centimeters to tens of meters. Some flows are massive but in others features such as pillows and fine-grained volcaniclastic breccia were observed. Fine to medium-grained green tuff and lithic tuff up to $2 \mathrm{~m}$ thick with both graded and massive, homogeneous beds are present near the base of member A (fig. 3B). Notably, near the base is a diamictite unit (figs. 3C and 3D). This matrixsupported diamictite was documented in sections F1431 and F1433 that were about 700 meters apart. In F1433, the diamictite is 23 meters above the last outcrop of Frog quartzite. The intervening strata are either quartzite rubble or not exposed. The diamictite itself has two parts, the basal three meters are composed of fine sand-sized pink lithic matrix with up to boulder-sized clasts of quartzite, dolostone, and limestone. This is overlain by four meters of wacke matrix with sand-sized lithic fragments and up to boulder-sized clasts of quartzite. The upper contact is conformable with mafic volcaniclastic breccia. In F1431, the diamictite is 16 meters above the last Frog quartzite outcrop. It overlies green-black basalt, green tuff and lithic tuff, and finegrained volcaniclastic breccia. Directly below the diamictite is fine-grained volcaniclastic breccia. The 5 meter thick diamictite has a wacke matrix with gravel-pebble clasts of limestone, dolostone, siltstone, and white and gray quartzite, and laterally has clasts up to cobble and boulder sized. The upper contact with fine-grained volcaniclastic breccia appears to be conformable. The rest of member A is dominated by basalt with minor interbedded black, green, and maroon siltstone. Additionally, two thin beds of iron formation were observed, one near the base of member A, above the matrix-supported diamictite, and one near the top of member A (fig. 3E). Previously, Neoproterozoic iron formation has been classified into three facies, hematitic-jaspilite, hematitic-mud/ silt and ferruginous mud/silt (Halverson and others, 2011; Cox and others, 2016). Although the iron formation at Gataga Mountain is not as extensive as in the Rapitan Group to the north, it displays features similar to the hematitic-mud facies, with mm-laminations that are defined by the relative concentrations of gray hematite and red siltstone. Irregular pods of gray limestone and orange- brown weathering dolostone are also present (fig. 3F). These pods were not in bed form, but were found as patchy replacement textures within volcanics and so were interpreted as secondary due to this irregular and replacing nature.

The Gataga intrusive unit is composed of medium to very coarse grained amalgamated green mafic sills, up to $100 \mathrm{~m}$ thick. This is followed by about $200 \mathrm{~m}$ of member B, which is dominated by dark green basalt with interbedded maroon to green siltstone. Near the base, member B consists of thin mafic flows and siltstone. Up-section, the flows are more massive, and preserve columnar jointing. The uppermost flows of member $\mathrm{B}$ are dominated by pillow basalts.

Member $\mathrm{C}$ is approximately $400 \mathrm{~m}$ thick and composed of light green vesicular and pillowed basalt and andesite together with volcaniclastic flows. The volcaniclastic units are generally massive and contain rounded to angular fragments in a coarsegrained chloritic matrix. Some of the volcaniclastic units contained large block and ash breccia (fig. 3G), weakly flattened volcanic clasts (fig. 3H) and high-energy volcaniclastic deposits that preserve festoon cross-bedding (fig. 3I). Finally, a clast was found within member $\mathrm{C}$ volcanic breccia that displayed antidune cross-bedding (fig. 3J).

Member $\mathrm{D}$ is a felsic unit that is at least $400 \mathrm{~m}$ thick and dominated by volcaniclastic breccia, but also contains minor andesitic to rhyolitic flows and tuffs. Member D is preserved on dip-slopes southwest of Gataga Mountain, but is most clearly exposed at the informal Matulka Creek Ridge. Overall, the volcaniclastic rocks of 

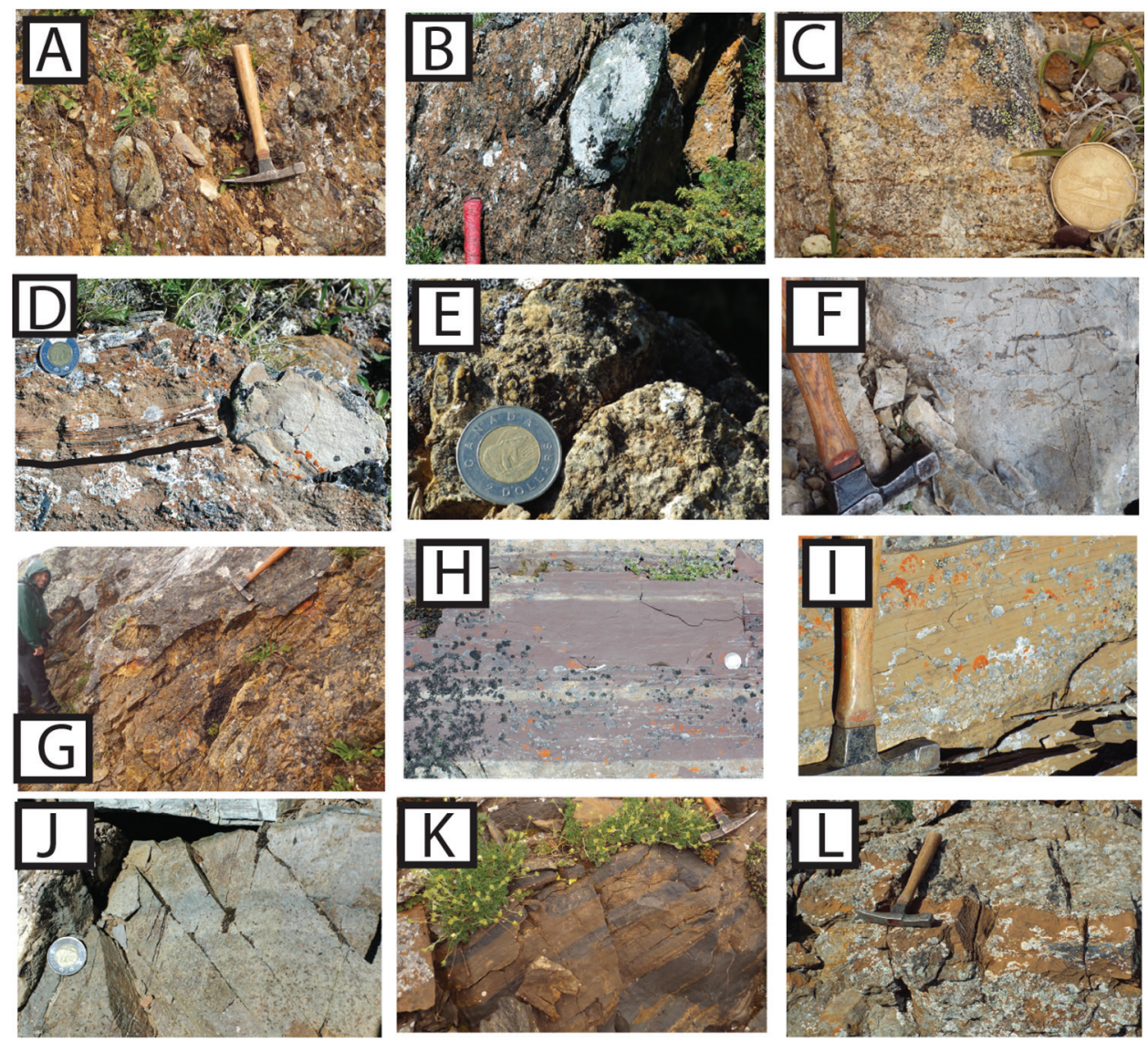

Fig. 4. Field photos. Gataga volcanics member D: (A) A1418 large sub-rounded granite clast in a felsic volcaniclastic breccia. (B) A1418 rounded rhyolite clast in a felsic volcaniclastic breccia, (C) A1418-343.2 ash, (D) A1418-355.4 diamictite unit with rhyolite dropstone puncturing laminations-this photo has been annotated to highlight deformed laminations. Matulka group: (E) A1417 lower oolitic carbonates, (F) A1418 lower recrystallized carbonate, (G) A1419 exposure surface, (H) A1417 maroon siliciclastics, (I) A1417 tan siliciclastics, (J) A1417 basalt flows, (K) A1419 interbedded oolitic limestone and siliciclastics, (L) A1417 volcanic breccia. Canadian loonie (28mm diameter), toonie (26.5mm diameter), or a hammer for scale.

member $\mathrm{D}$ are massive and very poorly sorted to unsorted. The bedding appears to be more prominent in exposure near the base of member D at Gataga Mountain, but more massive at exposures along Matulka Creek Ridge. Member D is dominated by breccia consisting of poorly sorted, angular to sub-rounded, green-white pumiceous felsic fragments ranging from several $\mathrm{mm}$ to $30 \mathrm{~cm}$ in diameter with a brown-orange weathering fine silt-sand sized matrix. Additionally, sub-rounded quartzite clasts were documented as well as carbonate and laminated siltstone clasts (figs. 3K and 3L), and large, rounded, rhyolitic and granitic clasts (figs. 4A and 4B). Orange-weathering carbonate cement is present within some of the volcaniclastic units. In addition to the massive volcaniclastic breccia, there are also bedded tuffaceous units (fig. 4C).

Within these fine units in the upper portions of member $\mathrm{D}$ there are also outsized clasts. These diamictite units include laminated and graded tuffaceous beds that contain larger angular carbonate clasts and a few isolated large rhyolitic clasts. In the upper part of these units, one particularly striking pale rhyolite clast appears to be a 
dropstone that deformed the laminated beds below (fig. 4D), but we cannot rule out the possibility that this is a volcanic bomb.

Finally, throughout member $\mathrm{D}$ are dispersed felsic flows. The flows are isolated, lenticular pale gray, aphanitic rhyolitic flows with phenocrysts of plagioclase and quartz. Member E succeeds member D and consists of dark brown weathering, intermediate to mafic, hornblende-bearing volcaniclastic breccia with abundant lapilli sized clasts.

Overlying the Gataga volcanics are siliciclastics, carbonates, and basalt of the Matulka group. The Matulka group is exposed in the anticline at Matulka Creek Ridge and undergoes dramatic facies changes across the anticline. The anticline is cut by several N-S trending high angle faults with up to $10 \mathrm{~m}$ of displacement. The contact between the overlying Matulka group and the volcanics is nowhere exposed and was not directly observed. Beds of member $\mathrm{E}$ of the Gataga volcanics may be truncated by the Matulka group, alternatively, there may be erosional features associated with the volcanics themselves or structural complications.

The lowermost unit of the Matulka group is a carbonate-dominated ridge former. The base consists of ooid grainstone that has been dolomitized and partially silicified (figs. 4E and 4F). Dolomitization and silicification is more pervasive in eastern sections, closer to the thrust faults carrying the stratigraphy. In section A1419, a karst surface is present $12.3 \mathrm{~m}$ from the base that is filled and overlain by massive orange to gray weathering quartzite (fig. 4G). This quartzite is followed by about $10 \mathrm{~m}$ of cover.

Overlying the basal unit is a recessive maroon siltstone (fig. $4 \mathrm{H}$ ) that is a slope former and thickens to the west. To the east, the maroon siltstone grades into brown-green siltstone and thinly bedded sandy dolostone (fig. 4I). These units include interbedded basalt flows (fig. 4J), with chilled margins and joints (Upper Gataga volcanics of Ferri and others, 1999). These are overlain by dark oolitic limestone and siliciclastic rocks including immature sandstone (fig. $4 \mathrm{~K}$ ) that interfinger with volcanic breccia that is dominated by cobble sized angular basalt clasts (fig. 3L).

To the north of our map area, additional strata were documented by Ferri and others (1999) that may be Cambrian in age and overlie the Matulka group. These include a quartzite unit (Csc, referred to as the Cambrian quartzite here and in fig. 1) of gray to white quartz sandstone and calcareous or dolomitic quartz sandstone. These are overlain by gray to buff-gray limestone and lesser dolostone $(\mathrm{Cl})$, that contain possible archaeocyathids, and finally, a siliciclastic unit of variable lithology (Cgm) that includes maroon and pale olive green, laminated siltstone, limestone, quartz sandstone and a maroon limestone-pebble conglomerate (Ferri and others, 1999). These strata can be traced northward where they interfinger with and are succeeded by more siliciclastic rocks of the Cambrian quartzite unit.

Additional siliciclastic dominated successions are present within thrust slivers just to the east of Gataga Mountain, as well as to the north (fig. 1), although the exact connection to other units is unclear due to numerous thrust faults that leave the sections hanging. To the east of Gataga Mountain, the B siliciclastic-carbonate unit includes interbedded light-blue-gray-pink cross-bedded carbonate interbedded with texturally and chemically mature medium bedded sandstone. To the north, the basal unit (A siliciclastic) consists of black to gray to brown siltstone and shale with red-yellow silty-dolostone near the top. This is overlain by the B siliciclastic unit that consists of siltstone interbedded with pink-yellow cross-bedded calcareous sandstone and sandy dolomite. Finally, on the west flank of the large anticline, the Gataga volcanics are succeeded by mature, bidirectional cross-stratified sandstone and quartzite of the Cambrian quartzite unit, which in turn is overlain by the Cambrian carbonate, a blue-gray to cream, white weathering recrystallized carbonate. The direct 
relationship of these Cambrian units to the A and B siliciclastic units and the other strata on the east side of the anticline is unclear.

The main differences from previous map based interpretations are that, first, instead of only less than 10 percent of the Gataga volcanics being felsic as previously estimated by Ferri and others (1999), by documenting the northward extent of the felsic volcaniclastic rocks of Member D, we have found that approximately 30 percent of the Gataga volcanics are felsic. Second, the B siliciclastic-carbonate unit exposed to the east of Gataga Mountain is not correlative with the Frog quartzite, and does not sit stratigraphically below the Gataga volcanics. The B siliciclastic-carbonate unit was suggested to be Late Proterozoic age after the initial dating of the volcanics (Ferri and others, 1999). We suggest that the contact between these units and the Gataga volcanics is a thrust fault and although complicated by additional thrust faults, and these units are likely Late Ediacaran to Early Cambrian in age. To the northwest, similar rocks are overturned where they are in contact with the main thrust fault. Finally, instead of a single "Gataga Mountain Anticline", the Gataga volcanics and Matulka group are exposed in two north plunging anticlines (fig. 1).

\section{$U-P b$ Geochronology}

F1431-5.5: Frog quartzite.-The sample was collected from the top of the Frog quartzite, a thick-bedded quartzite, tan to brown-red weathered and gray-tan fresh and cross-bedded (figs. 1 and 2). Throughout the quartzite there is additional iron staining and 0.5 centimeter thick quartz veins. The sample is composed of well-sorted millimetersized quartz grains with isolated dark lithic fragments. 146 detrital zircon grains were analyzed from sample F1431-5.5, of which 136 were $<10$ percent discordant (fig. 5, supplementary table S1, http:/ / earth.geology.yale.edu/\% 7eajs/SupplementaryData/ 2018/Eyster). The dominant age population is between 1246 to $920 \mathrm{Ma}$ (62 grains), with secondary peaks at 1710 to $1246 \mathrm{Ma}$ (39 grains), and 2008 to $1710 \mathrm{Ma}$ (18 grains). Smaller age populations are present between $c a$. 731 to $814 \mathrm{Ma}, 2253$ to $2321 \mathrm{Ma}$, and 2492 to 2664 Ma. CA-ID-TIMS analyses of four young grains yielded dates of: $735.8 \pm$ $0.6 \mathrm{Ma}, 737.2 \pm 0.6 \mathrm{Ma}, 741.3 \pm 0.6 \mathrm{Ma}$, and $742.3 \pm 0.6 \mathrm{Ma}$ (fig. $6 \mathrm{~F}$, table 1 ). This gives a maximum depositional age for the Frog quartzite of $<735.8$ Ma.

F1433-112; Lower Member A, Gataga volcanics. - A pink lithic volcaniclastic unit near the base of the Gataga volcanics, in the lowermost part of Member A (figs. 1 and 2). The sample is orange weathering and pink-yellow fresh, supported by fine-sand to pebble sized clasts of pale-white aphanitic rhyolite, flattened yellow and darker flattened maroon clasts and a matrix that included fine lithic clasts, aphantic pink volcaniclastic material and muscovite. 116 detrital zircon grains were analyzed from sample F1433-112, of which 97 were $<10$ percent discordant (fig. 5, supplementary table S1, http://earth.geology.yale.edu/\% 7eajs/SupplementaryData/2018/Eyster). The dominant age population is between 2060 to 1780 Ma (41 grains). Smaller age populations at 1090 to $961 \mathrm{Ma}$ (12 grains), and 840 to $655 \mathrm{Ma}$ (6 grains). CA-ID-TIMS analyses of six young grains yielded dates of 707.6 $\pm 0.5 \mathrm{Ma}, 711.6 \pm 0.5 \mathrm{Ma}, 726.2 \pm$ $0.5 \mathrm{Ma}, 726.7 \pm 1.0 \mathrm{Ma}, 729.8 \pm 0.8 \mathrm{Ma}$ and $734.7 \pm 1.4 \mathrm{Ma}$ (fig. $6 \mathrm{~F}$, table 1 ). This gives a maximum depositional age for the base of the Gataga volcanics of $<707$ Ma.

F1431-241: Upper Member A, Gataga volcanics. -A green volcaniclastic sandstone near the top of Member A of the lower Gataga volcanics (figs. 1 and 2), orange weathering and dominantly blue-gray fresh with small millimeter-sized crystals of quartz, plagioclase feldspar, dark mafic fragments, as well as orange weathering iron dominated mafic fragments. The clasts were aligned parallel to foliation in a matrix that was blue-gray and aphanitic. 111 detrital zircon grains were analyzed from sample F1431-241, of which 89 were $<10$ percent discordant (fig. 5, supplementary table S1, http:/ / earth.geology.yale.edu/\% 7eajs/SupplementaryData/2018/Eyster). The dominant age population is between 830 to $642 \mathrm{Ma}$ (30 grains). Smaller age populations are 


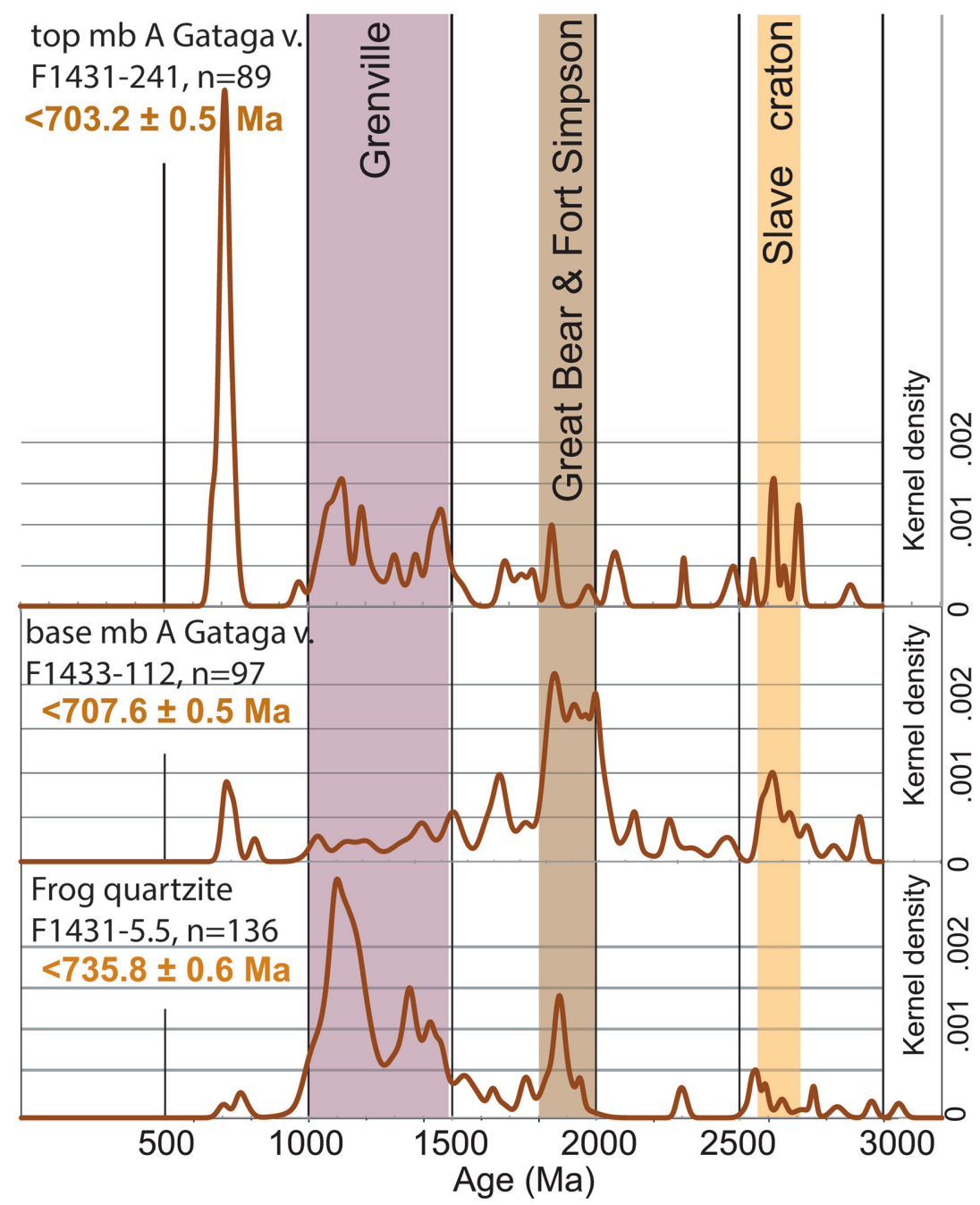

Fig. 5. Detrital spectra normalized probability plots of U-Pb dates obtained by LA-ICP-MS on zircon collected from samples F1431-5.5, F1433-112 and F1431-241. Regional basement and orogenic events that could correspond to the data peaks are highlighted.

between 1567 to 907,1888 to $1654 \mathrm{Ma}, 2100$ to $2010 \mathrm{Ma}$, and 2773 to $2418 \mathrm{Ma}$. CA-ID-TIMS analyses of 12 young grains yielded dates of $c a .703$ to $705 \mathrm{Ma}(\mathrm{n}=3), c a$. $712 \mathrm{Ma}(\mathrm{n}=8)$, and $c a .715 \mathrm{Ma}(\mathrm{n}=1)$ (fig. $6 \mathrm{~F}$, table 1$)$. The youngest crystal implies a maximum depositional age for the top of member A of the Gataga volcanics of $<703$ Ma.

A1416-8.6: Middle Member D, Gataga volcanics.-A pale blue-green foliated aphanitic rock with isolated millimeter sized quartz crystals and plagioclase phenocrysts that was the resampled location of Ferri and others (1999). There were no discernable clasts in hand sample and could be an effusive rhyolitic flow. 6 of the 8 dated zircon grains yielded concordant analyses with a weighted mean ${ }^{206} \mathrm{~Pb} /{ }^{238} \mathrm{U}$ date of $696.24 \pm$ $0.22 \mathrm{Ma}(\mathrm{MSWD}=1.93$ ), which is interpreted as the eruptive age (fig. $6 \mathrm{~A}$, table 1 , table 2). Two crystals (Z2 and Z8) not included in this date are older $(698.65 \pm 0.77 \mathrm{Ma}$ $699.44 \pm 0.48 \mathrm{Ma})$ and interpreted as inherited grains. 

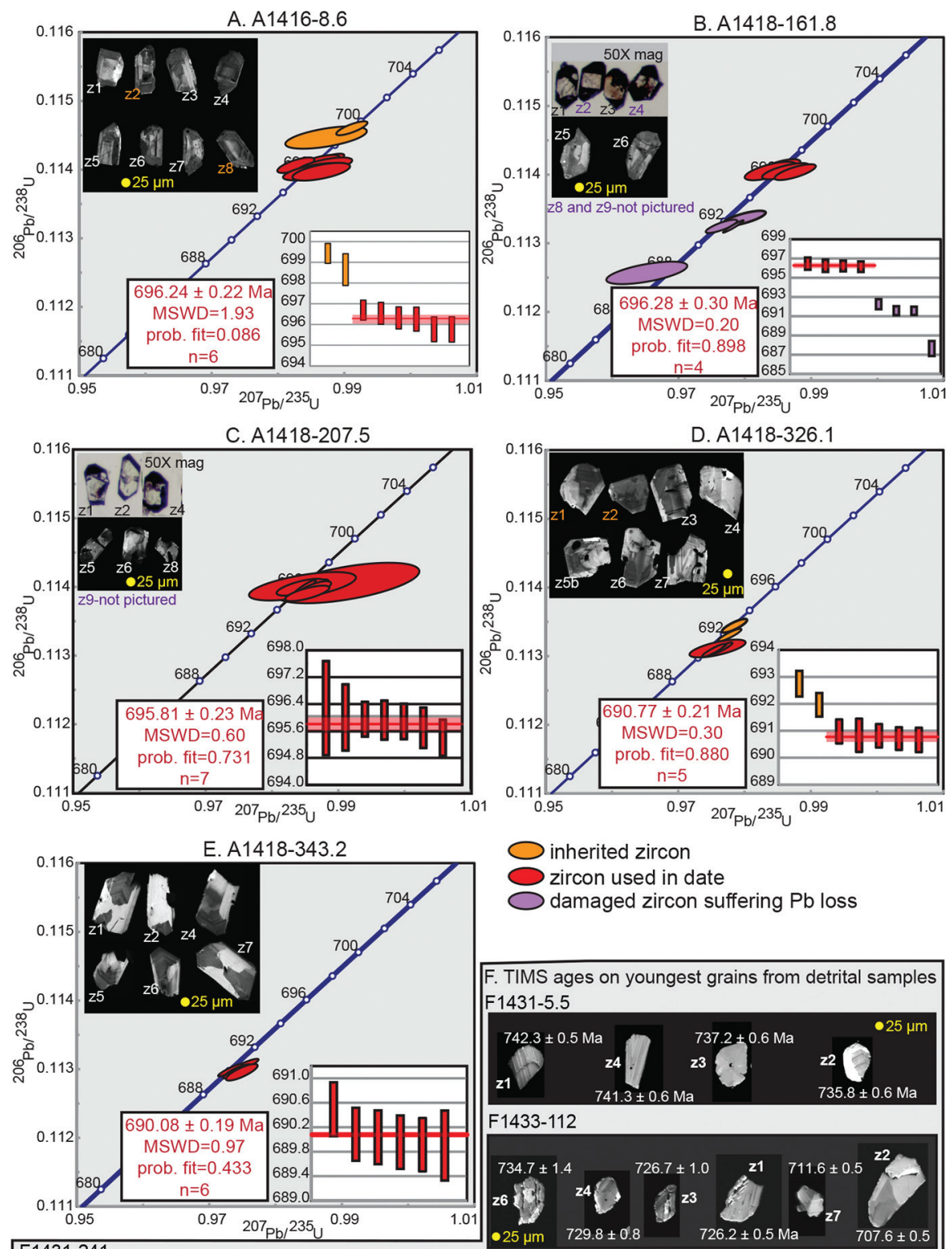

F1433-112
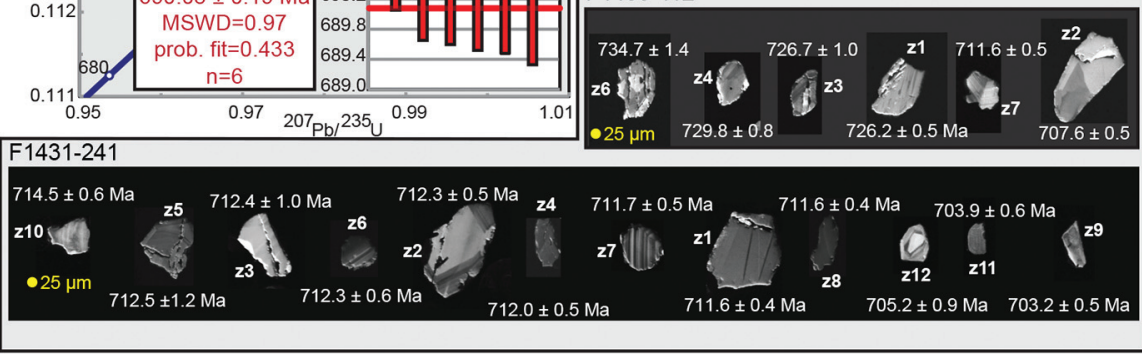

Fig. 6. Concordia diagrams of zircon ${ }^{206} \mathrm{~Pb} /{ }^{238} \mathrm{U}$ CA-ID-TIMS dates with ranked age diagrams as insets: (A) A1416-8.6-rhyolite from member D near Gataga Mountain, (B) A1418-161.8-volcaniclastic andesite from member D on Matulka Creek Ridge, (C) A1418-207.5-rhyolite from member D on Matulka Creek Ridge, (D) A1418-326.1-felsic laminated tuff just below diamictite units, (E) A1418-343.2-felsic laminated tuff between two diamictite units. The data point error ellipses are $2 \sigma ;(\mathrm{F})$ CL images of youngest grains from the detrital samples F1431-5.5, F1433-112, and F1431-241 along with TIMS dates. 


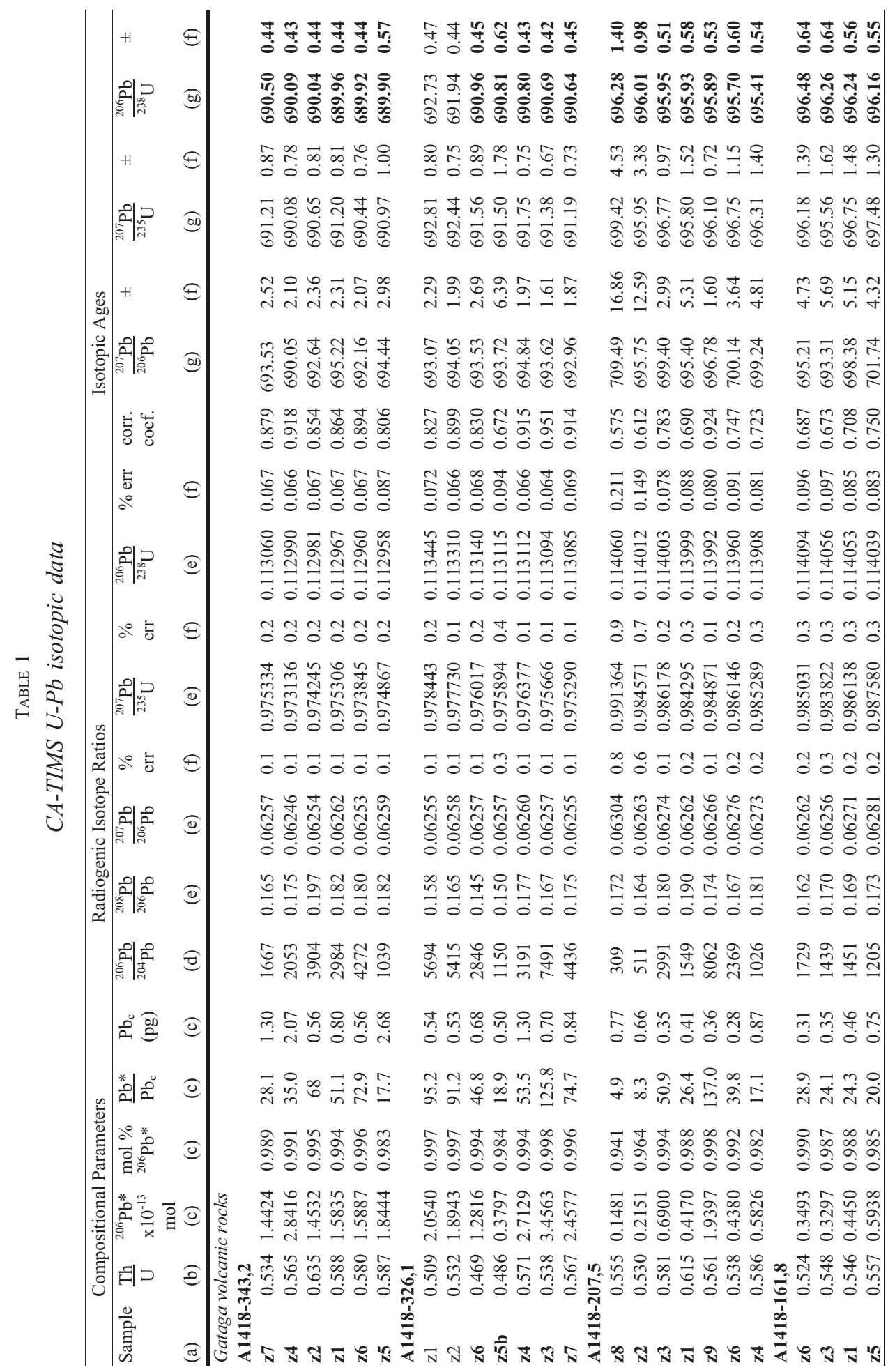




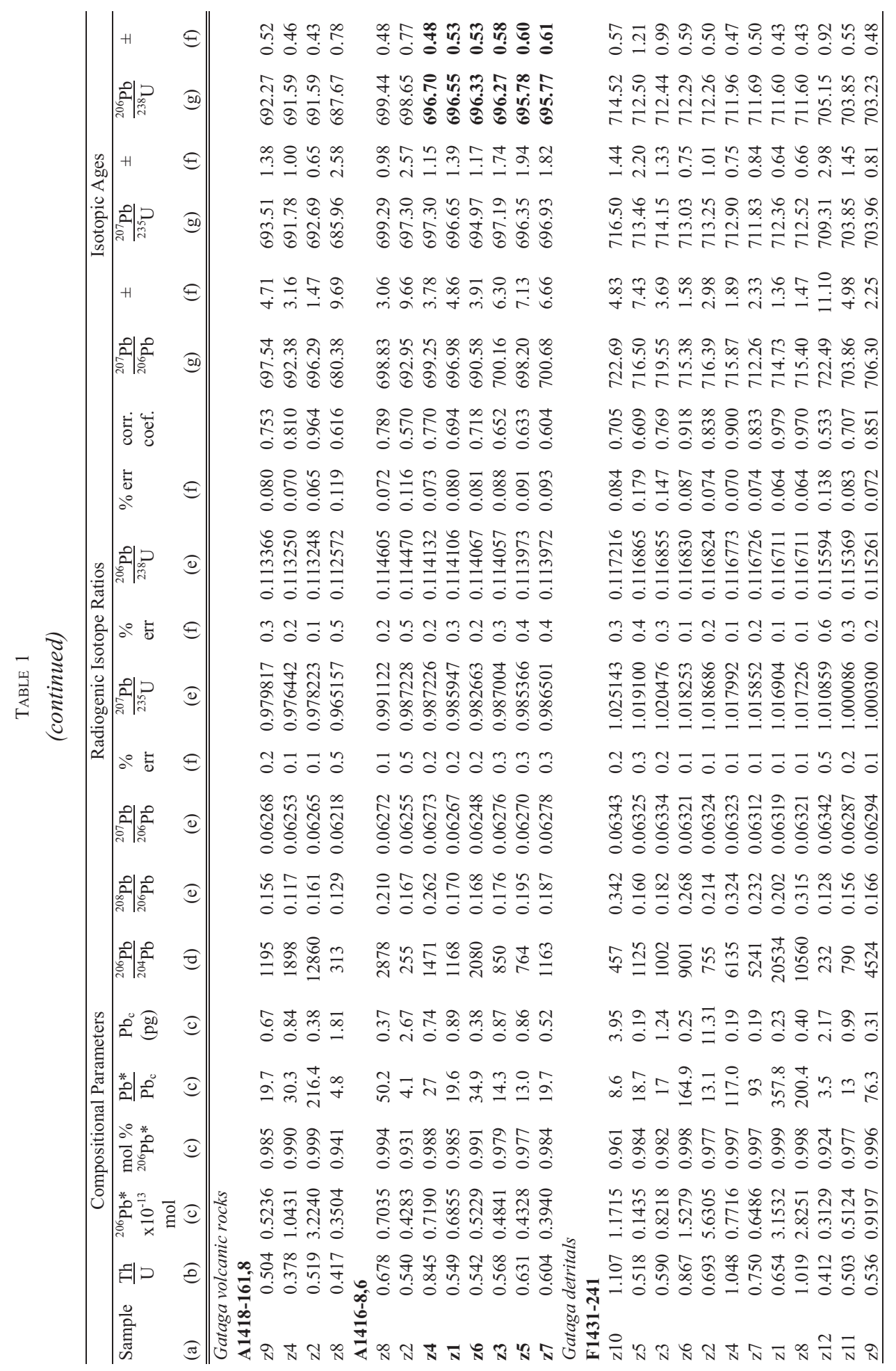




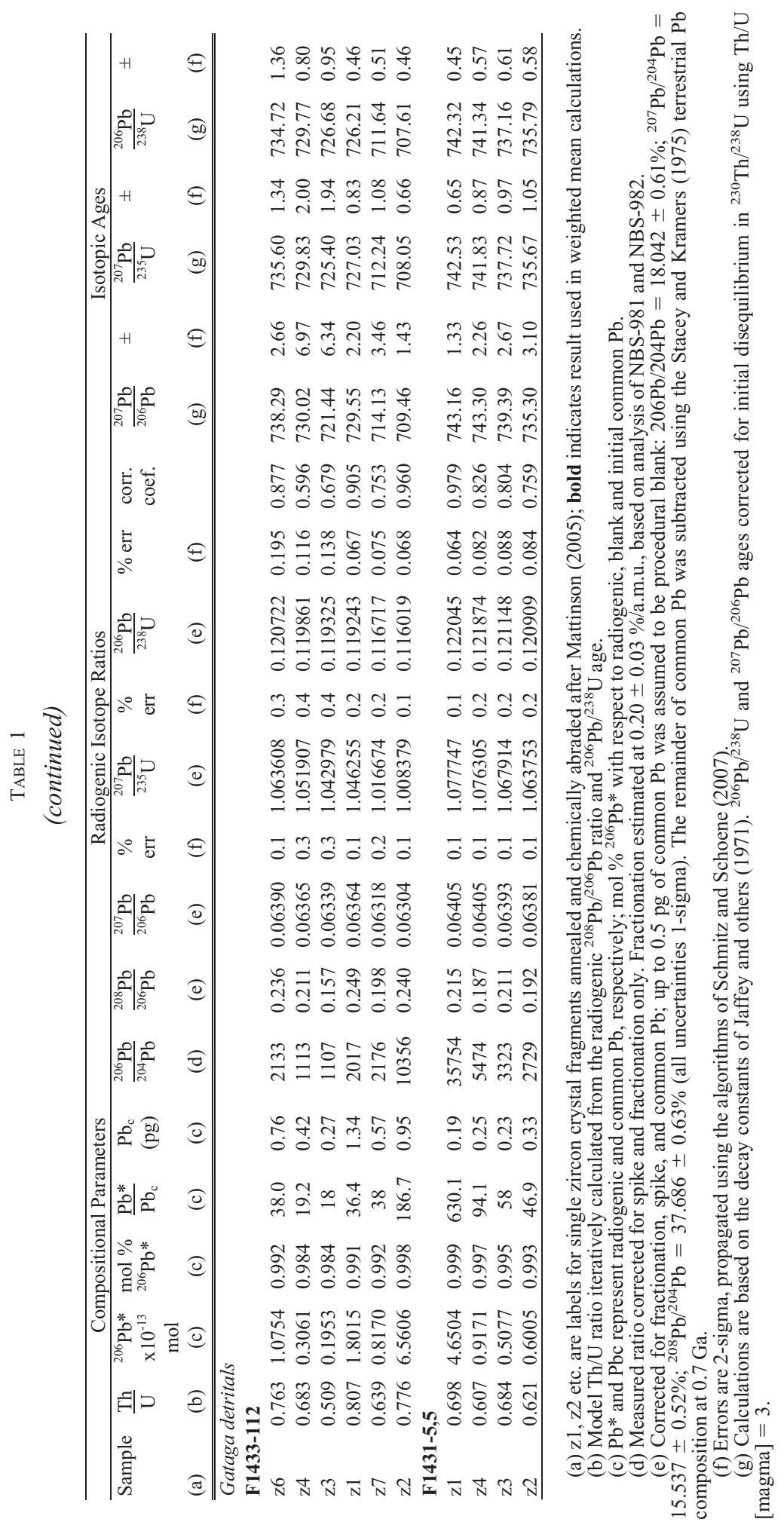


TABLE 2

Weighted Mean Age Calculations for Volcanic Samples

\begin{tabular}{lccccc}
\hline & Lithology & $\begin{array}{c}{ }^{206} \mathrm{~Pb} /{ }^{238} \mathrm{U} \text { age } \pm 2 \sigma(\mathrm{Ma}) \\
\text { analytical }(+ \text { tracer })[+\lambda]\end{array}$ & $\mathrm{n}^{\#}$ & MSWD $^{*}$ & prob. fit* \\
\hline \hline A1418-343.2 & rhyolite tuff & $690.08 \pm 0.19(0.38)[0.80]$ & 6 & 0.97 & 0.433 \\
A1418-326.1 & rhyolite tuff & $690.77 \pm 0.21(0.39)[0.81]$ & 5 & 0.30 & 0.880 \\
A1418-207.5 & rhyolite lava & $695.81 \pm 0.23(0.4)[0.82]$ & 7 & 0.60 & 0.731 \\
A1418-161.8 & andesite tuff & $696.28 \pm 0.30(0.44)[0.84]$ & 4 & 0.20 & 0.898 \\
A1416-8.6 & rhyolite lava & $696.29 \pm 0.22(0.40)[0.82]$ & 6 & 1.93 & 0.086 \\
\hline
\end{tabular}

\# indicates number of zircons included, see bolded ages in table 1.

* MSWD = mean squared weighted deviation; prob. fit = probability of fit.

A1418-161.8: Middle Member D, Gataga volcanics. - A massive blue-colored andesite with larger plagioclase feldspar crystals that is gray-brown weathering and gray fresh with an aphanitic matrix with biotite crystals, and includes 5 millimeter long angular gray quartz-rich lithic fragments and pale white plagioclase fragments that are 1 millimeter long. The biotite dominated regions formed bands parallel to foliation. This appeared to be a volcaniclastic rock resulting from explosive eruption. Four of the dated zircon grains yielded concordant and equivalent analyses with a weighted mean ${ }^{206} \mathrm{~Pb} /{ }^{238} \mathrm{U}$ date of $696.28 \pm 0.30 \mathrm{Ma}(\mathrm{MSWD}=0.20)$, which is interpreted as the eruptive age (fig. $6 \mathrm{~B}$, table 1 , table 2 ). The four grains that were not included have a scatter of ages of that are younger $692.27 \pm 0.52 \mathrm{Ma}, 691.59 \pm 0.46 \mathrm{Ma}, 691.59 \pm 0.43$ $\mathrm{Ma}, 687.67 \pm 0.78 \mathrm{Ma}$, likely due to persistent lead loss in the sampled zircons, which is consistent with CL images that display dark regions damaged by radioactive decay.

A1418-207.5: Middle Member D, Gataga volcanics. - This unit was green-brown weathering, pale gray to pale green fresh aphanitic matrix with interlocking mm-sized quartz phenocrysts. There were biotite dominated bands subparallel to foliation and rust-weathering iron-rich veins scattered throughout. This likely effusive rhyolite lava flow was of short lateral extent and was interbedded with felsic volcanic breccia. All seven of the dated zircon grains yielded concordant analyses with a weighted mean ${ }^{206} \mathrm{~Pb} /{ }^{238} \mathrm{U}$ date of $695.81 \pm 0.23 \mathrm{Ma}(\mathrm{MSWD}=0.6)$, which is interpreted as the eruptive age (fig. $6 \mathrm{C}$, table 1 , table 2 ).

A1418-326.1: Upper Member D, Gataga volcanics.-An orange weathering, pale blue-gray fresh volcaniclastic rock, dominated by 2 to 6 millimeter-long fine-grained pale blue-white lithic fragments as well as dark-green to black lithic fragments. The unit spanned three meters, encompassing multiple beds up to $70 \mathrm{~cm}$ thick. Overlying this explosive volcaniclastic tuff were brown weathering laminated beds of orange brown siltstone and darker quartzite. Five of the seven dated zircon grains yielded concordant and equivalent analyses with a weighted mean ${ }^{206} \mathrm{~Pb} /{ }^{238} \mathrm{U}$ date of $690.77 \pm 0.21 \mathrm{Ma}$ $(\mathrm{MSWD}=0.30)$, which is interpreted as the eruptive age (fig. $6 \mathrm{D}$, table 1 , table 2$)$. The two grains that were not included (Z1 and Z2) are interpreted as inherited grains as they had slightly older dates of $692.73 \pm 0.47 \mathrm{Ma}$ and $691.94 \pm 0.44 \mathrm{Ma}$.

A1418-343.2: Upper Member D, Gataga volcanics.—An orange weathering, gray-pink fresh coarse pale volcaniclastic tuff that is clast supported and dominated by 2 to 4 millimeter-long pink feldspar and clear quartz crystals, 5 millimeter-long angular fragments of gray quartz. The matrix is aphantic but includes some green-brown biotite crystals. The tuff is $4 \mathrm{~m}$ thick, and the outcrop was traced laterally for $10 \mathrm{~m}$ before the exposures became poor, at the base of the unit there are centimeter-sized pale felsic volcanic clasts. This tuff overlies fine laminated beds with outsized clasts and 

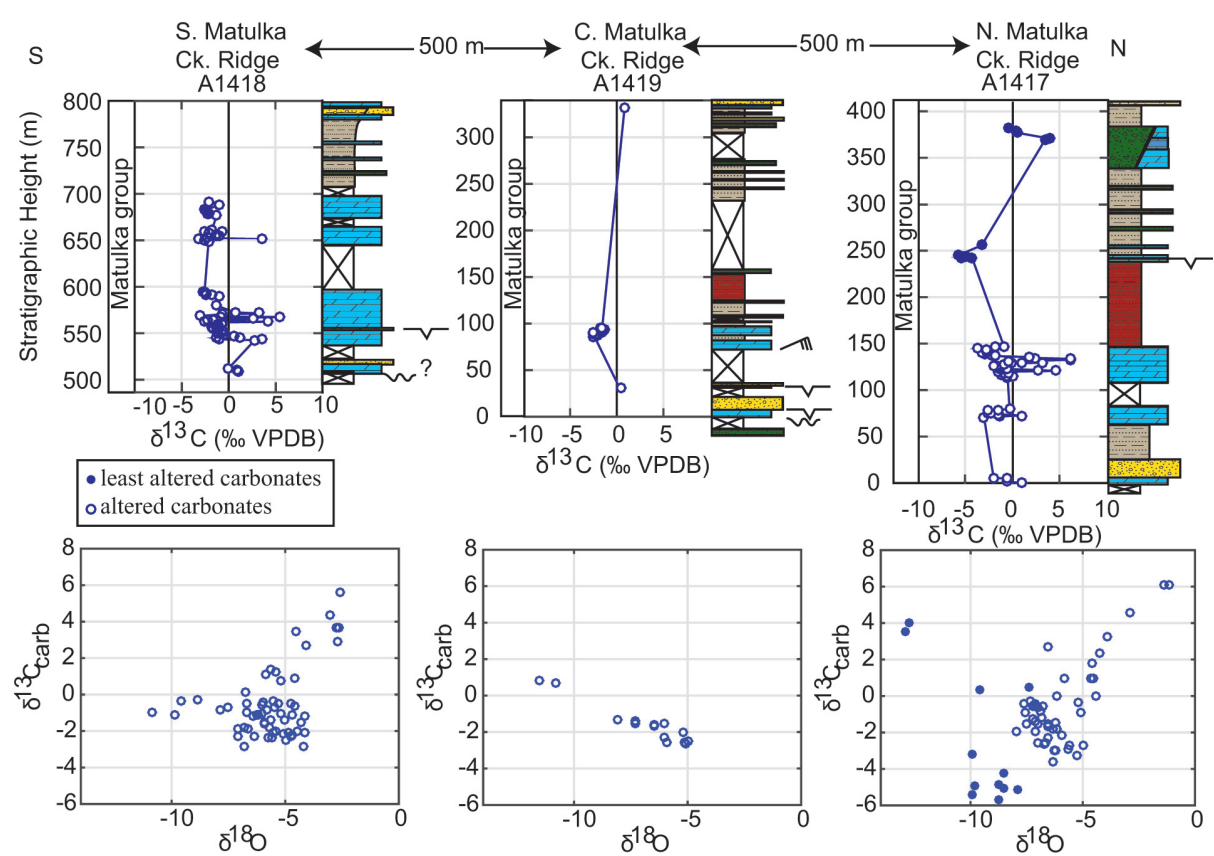

Fig. 7. Top row: Matulka group stratigraphic sections and carbon isotope data. Bottom row: corresponding carbon-oxygen cross plots. See figure 1 for location of sections, and figure 2 for lithology key.

is about 10 meters below the large felsic dropstone that penetrates the laminated beds below (fig. 4D). All six dated zircon grains yielded concordant and equivalent analyses with a weighted mean ${ }^{206} \mathrm{~Pb} /{ }^{238} \mathrm{U}$ date of $690.08 \pm 0.19 \mathrm{Ma}(\mathrm{MSWD}=0.97)$, which is interpreted as the eruptive age (fig. $6 \mathrm{E}$, table 1, table 2 ).

\section{Chemostratigraphy}

The basal carbonates of the Matulka group are pervasively recrystallized, with carbonate veins and fabric destructive dolomite decimating most of the primary sedimentary structures (fig. 4F). Isotope data from these units are extremely scattered (fig. 7, supplementary table S3, http://earth.geology.yale.edu/\%7eajs/Supplementary Data/2018/Eyster). In one section, A1417, limestone with primary textures are preserved. Data from these samples is less scattered and preserves stratigraphic trends (fig. 7 , supplementary table S3). Particularly, these samples record a negative $\delta^{13} \mathrm{C}_{\text {carb }}$ excursion, with values trending from -4.22 permil to -5.72 permil and then returning to +3.99 permil and back to values just under 0 permil (fig. 7). Carbon-oxygen cross-plots for the basal carbonates in the Matulka group display covariance, possibly resulting from meteoric diagenesis (fig. 7).

\section{DISCUSSION}

\section{Geochronology}

Magmatic ages.-Based on sections A1418 and A1416, the final reported dates and uncertainties of the Gataga volcanics are weighted mean dates from populations of single zircons (fig. 8, table 2). This approach weights each individual analysis according to its precision, so analyses with a small uncertainty contribute more to the weighted mean than those with larger uncertainty. The mean squared weighted deviation (MSWD) measures the coherence of the dataset and the scatter of the data 


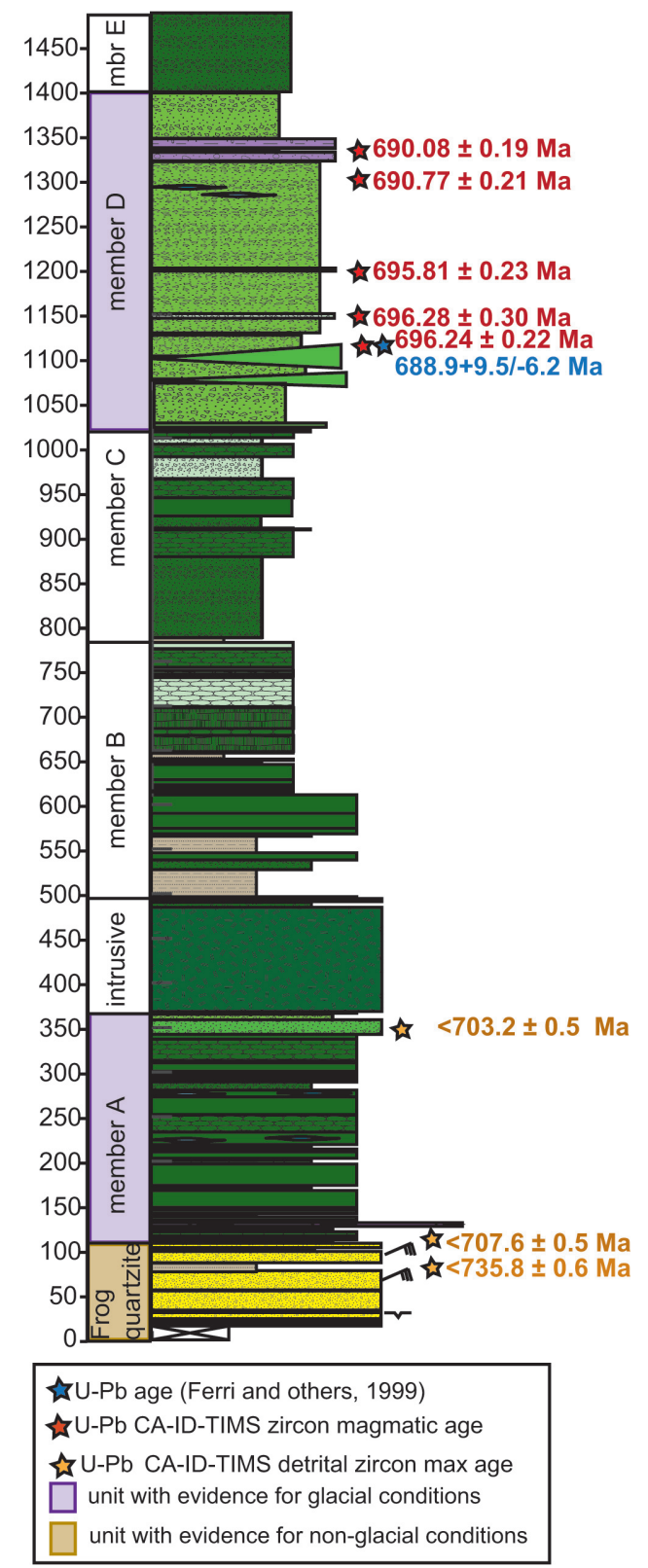

Fig. 8. Composite stratigraphy and geochronology results with magmatic ages for samples A1416-8.6, A1418-161.8, A1418-207.5, A1418-326.1, and A1418-343.2. See figure 2 for lithology key.

that can be considered due to analytical factors alone and varies according to the number of data points in the calculation (Wendt and Carl, 1991; Condon and Bowring, 2011). The calculation of the weighted mean date is based on the assumption of a single population with normally distributed errors, which requires eliminating all zircons that suffer from lead loss or that are inherited (Condon and Bowring, 2011). 
With regard to lead loss, the effects can be minimized by the selection of the best quality zircon grains and aggressive chemical abrasion. Lead loss may still influence some high-U zircon grains, but can be identified with high precision analyses (Bowring and others, 2006). Only in A1418-161.8 were there were four grains that we interpreted as experiencing lead loss and were excluded from the mean date (fig. 6B). Inheritance of older zircon grains can be a common occurrence in magmatic systems, through the assimilation of the host rock, including only slightly older volcanic and plutonic rocks. Older crystals or crystal with inherited cores can comprise more than 50 percent of the zircons recovered from an ash (Bowring and others, 2006). For our samples, A1416-8.6 and A1418-326.1 both had two grains that we interpreted as inherited (figs. 6A and $6 \mathrm{D})$.

Despite the presence of a minority of zircon dates compromised by Pb-loss or inheritance, the majority clusters of dates from the same A1418 section of member D (fig. 8), conform to the constraints of stratigraphic superposition in their range from $696.28 \pm 0.30$ Ma near the base to $690.08 \pm 0.19$ Ma near the top. This ordering lends credence to the objectivity of our age assignments. The weighted mean dates for the majority clusters of zircons in samples from A1418 and A1416 are further interpreted as volcanic eruptive ages, as they are measured from stratigraphic horizons illustrating effusive and pyroclastic textures.

The efficacy of chemical over air abrasion is illustrated by sample A1416-8.6; the legacy age for this volcanic unit from Ferri and others (1999) was obtained on zircons that underwent air-abrasion to assist in removing the outer portions of crystals more likely to have experienced lead loss. Five zircon fractions were analyzed and a York II best-fit regression line through these variably discordant populations gave an upper intercept ${ }^{206} \mathrm{~Pb} /{ }^{238} \mathrm{U}$ of $688.9+9.5 /-6.2 \mathrm{Ma}$ or a ${ }^{207} \mathrm{~Pb} /{ }^{206} \mathrm{~Pb}$ age of $689.1 \pm 4.6 \mathrm{Ma}$. Our age of $696.24 \pm 0.82 \mathrm{Ma}$ for the same horizon, based upon concordant and equivalent ${ }^{206} \mathrm{~Pb} /{ }^{238} \mathrm{U}$ dates, is $\sim 7 \mathrm{Ma}$ older due to the better mitigation of ancient lead loss using chemical abrasion, which accesses and removes high-U open-system domains throughout the crystal. Combined with our eruptive ages for section A1418, this new age verifies our correlation between the exposures of the base of member $\mathrm{D}$ at Matulka Creek ridge, with the $696.28 \pm 0.30 \mathrm{Ma}$ at the base, with the $696.24 \pm 0.22 \mathrm{Ma}$ rhyolite from member D west of Gataga Mountain (fig. 8).

Detrital spectra.-The detrital zircon spectra record a shift in sources between the Frog quartzite and the basal Gataga volcanics (fig. 5). Specifically there appears to be a more cosmopolitan source for the Frog quartzite and a more local source or a source similar to the Great Bear Lake magmatic zone or Slave craton for the basal Gataga volcanics. The spectra from the Frog quartzite is similar to data from Tonian quartzites elsewhere in the Cordillera that are interpreted to have been transported via a transcontinental river system and recycling of material from the Grenville clastic wedge in northeast Laurentia (Dehler and others, 2010; Rainbird and others, 2012; Yonkee and others, 2014). The textural and compositional maturity of the Frog quartzite is also consistent with long transport. Similar lithological controls on detrital zircon spectra have been observed in other Neoproterozoic units on Laurentia where mature sandstone contains abundant grains interpreted to have been sourced from the distal provinces, whereas feldspathic quartzites tend to have more grains sourced from more local provinces (Dehler and others, 2010; Yonkee and others, 2014). The ca. $740 \mathrm{Ma}$ detrital ages in the Frog quartzite and the $c a$. 730 Ma detrital zircons in the basal Gataga volcanics could be sourced from basement, such as the 736+23/-17 Ma Hugh Allan gneiss (U-Pb zircon McDonough and Parrish, 1991) and the $728+9 /-7 \mathrm{Ma}$ Deserters Range Gneiss (U-Pb zircon Evenchick, 1988). However, these are imprecise ages, and examination of the original data reveals evidence for inheritance.

Later, during the eruption of the Gataga volcanics we suggest that tectonic activity associated with sedimentation and volcanism could have brought local sources to the 

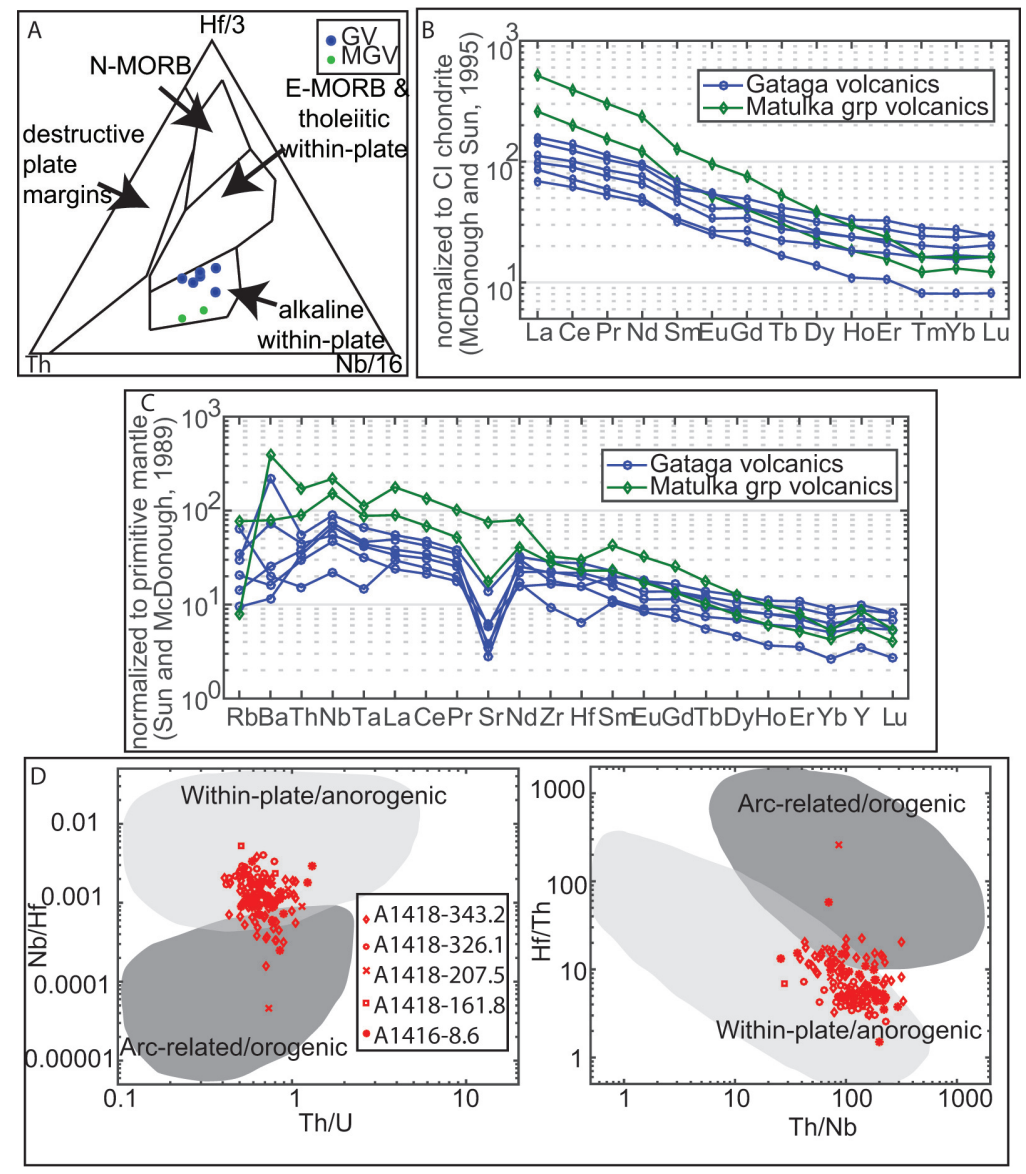

Fig. 9. Volcanic zircon and bulk geochemistry: (A) Wood diagram using geochemical data from the mafic Gataga volcanics (PGm of Ferri and others, 1999) and mafic Matulka group volcanics (CPv of Ferri and others, 1999), (B) CI Chondrite normalized REE spider diagram for the mafic volcanics, data from Ferri and others (1999), (C) Primitive mantle normalized spider diagram for the mafic volcanics, data from Ferri and others (1999), (D) Tectonic setting discrimination diagrams following figure 8 Yang and others (2012), overlaid with geochemical data from member $\mathrm{D}$ zircons.

surface. Thus the $c a .711$ to 714 Ma zircon grains in the base of the Gataga volcanics could be locally sourced. Alternatively, they could be from the 723 to 711 Ma Franklin LIP to the north (Heaman and others, 1992; Denyszyn and others, 2009a; Denyszyn and others, 2009b).

\section{Igneous Geochemistry}

No new bulk geochemical data was collected, as data was already available from both the Gataga volcanics and the Matulka group volcanics (Table 2 of Ferri and others, 1999). Geochemical data from mafic rocks was replotted on the $\mathrm{Th} / \mathrm{Hf} / \mathrm{Nb}$ triangular discrimination diagram (fig. 9A) of Wood (1980). Data clusters for both the Gataga volcanics (PGm of Ferri and others, 1999) and the Matulka group volcanics (CPv of Ferri and others, 1999) fall in the alkaline within-plate basalts field.

Additionally, when the normalized REE and trace elements are examined (trace elements normalized to primitive mantle of Sun and McDonough 1989, and REE 
normalized to CI chondrite of McDonough and Sun, 1995), the data from the Matulka group volcanics display steeper signatures and depletion in heavier elements than data from the Gataga volcanics (figs. 9B and 9C). These differences suggest that the Matulka group volcanics are geochemically distinct from the Gataga volcanics.

New geochemical data (supplementary table S2, http://earth.geology.yale.edu/ $\% 7$ eajs/SupplementaryData/2018/Eyster) from the zircon extracted from member D and dated with LA-ICPMS were plotted on $\mathrm{Nb} / \mathrm{Hf}$ versus $\mathrm{Th} / \mathrm{U}$ and $\mathrm{Th} / \mathrm{Nb}$ versus $\mathrm{Hf} / \mathrm{Th}$ discrimination diagrams following the work of Yang and others (2012). The data from the Member D of the Gataga volcanics (fig. 9D) generally fall in the field of within-plate magmatism rather than the arc/orogenic field (Yang and others, 2012), consistent with volcanism related to anorogenic magmatism, such as rift-related magmatism.

\section{Depositional Setting}

Frog quartzite. - Cross-bedded sandstone, including tidally influenced bidirectional cross-stratification, and mud-cracks, indicate that the Frog quartzite was deposited in a shallow intertidal, shoreface or braided river environment without evidence for glaciation (table 3). This is somewhat consistent with the original interpretation of Ferri and others (1999); however, we suggest that this was a clastic dominated succession, not carbonate dominated. This is because we interpret the carbonates to the east of the Gataga Mountain thrust as being different from the Frog quartzite and deposited much later, the carbonates within the Gataga volcanics as being diagenetic carbonates, and the Matulka group carbonate strata as significantly younger.

Gataga volcanics.-As the depositional environment of the Gataga volcanics is intimately connected to the interpretation of the exotic clasts and origin of the diamictites, we will first focus broadly on the various acceptable depositional environments for members A-E, and then address the possibility of glacial influence (table 3 ).

The interbedded mafic pillow lavas, massive flows, fine-grained volcaniclastic breccia and interbedded siltstone of member A are consistent with submarine to sub-ice shelf eruptions, as pillows are a distinct feature of basaltic lavas erupted under water or ice. The fine-grained volcaniclastic breccia could be submarine epiclastic deposits, and laminated siltstone further suggests a deeper-water setting. Up-section, the deposition of interbedded mudstone, siltstone, massive mafic flows, and pillow basalts of member B suggest sedimentation in relatively quiescent water interrupted by volcanism that could be, at least in part, representative of a sub-aqueous or sub-ice shelf environment. Member B also contains massive flat-topped flows with columnar joints, which can form from rapid cooling due to post-solidification thermal contraction typical of subaerial flows, but is also found in subglacial eruptions (Tuffen and others, 2001; Edwards and others, 2002). The pillows, flows and volcaniclastic breccias of member $\mathrm{C}$ along with festoons and block and ash flows suggest higher energy pyroclastic deposits interbedded with effusive flows. The increased abundance of breccia in member $\mathrm{C}$ compared with members A and B below could reflect a slightly more evolved magma composition and increased magma viscosity, but could also be related to increased volatile content or decreased hydroclastic pressures. It is difficult to determine if the deposits are subaqueous or subglacial pyroclastic deposits or epiclastic deposits. The angular antidune clast suggests that the eruptions included fast low-density pyroclastic deposits (Cas and Wright, 1987). Subaqueous eruptions might produce dense pumiceous quench fragmented blocky hyaloclastite fragments of silicic glass and hyaloclastite debris flow deposits. The combination of pillows and pyroclastic flows suggests that member $\mathrm{C}$ was deposited in a shallow subaqueous or subglacial environment. The massive felsic volcaniclastic deposits of member D could represent subaqueous or subglacial eruptions, in the form of hydrothermal explosion breccias, 


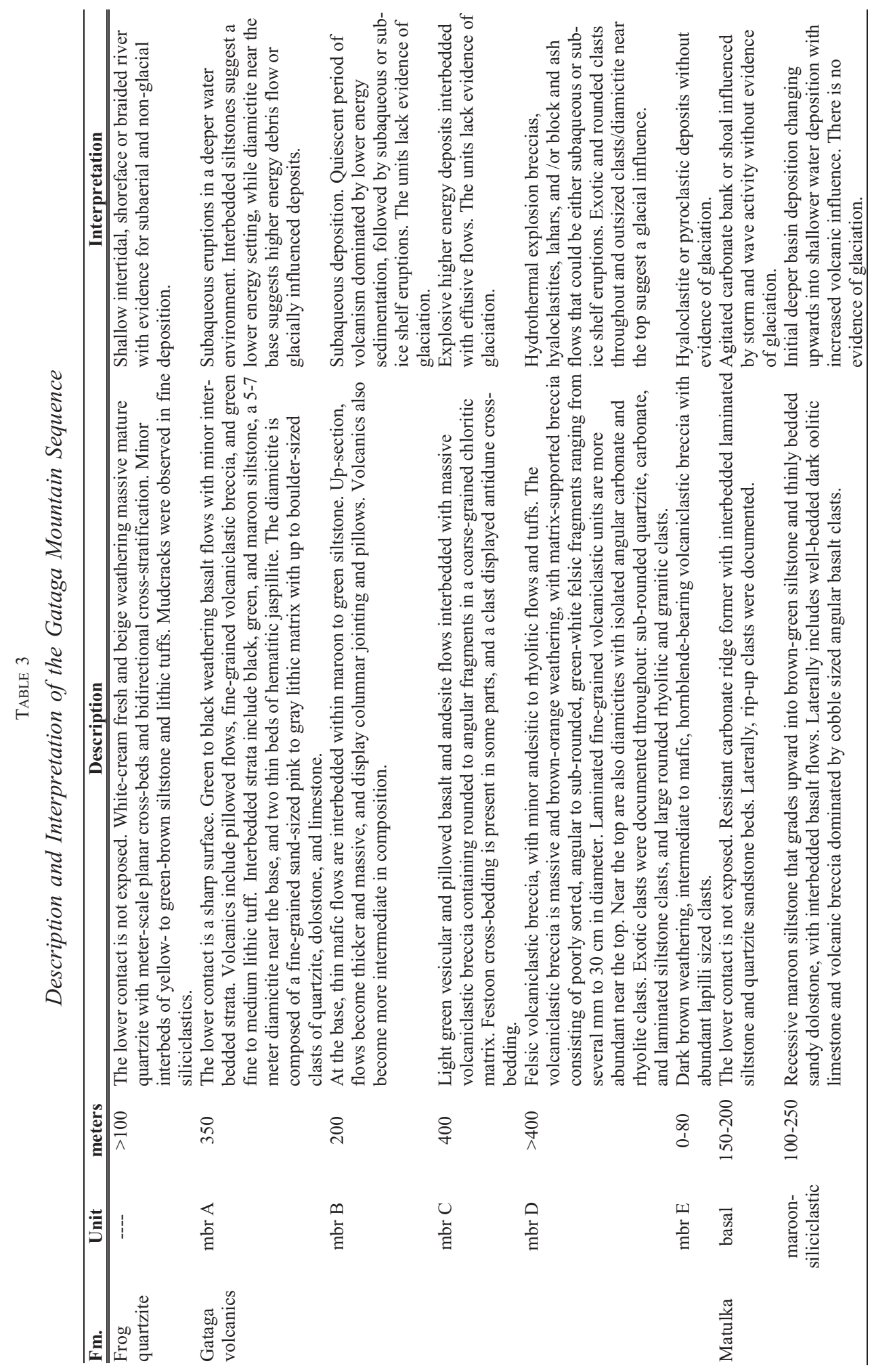


hyaloclastites, lahars, and block and ash flows. Near the top of member D, the thinly laminated volcanic beds could be indicative of airfall ashes and tuffs, ground or ash-cloud surge deposits, or epiclastic reworking of volcanically derived sediment. The poorly exposed mafic gravel sized volcaniclastic deposits of member E mark a return to more primitive magma composition. These rocks are poorly bedded and could represent hydroclastic or pyroclastic deposits.

In summary, the Gataga volcanics sharply overly the Frog quartzite and begin with subaqueous or subglacial mafic volcanism, and followed by continued maficintermediate subaqueous volcanism that interrupted relatively deep-water deposition of graded beds of siltstone interpreted as thin turbidites (member A). Volcanism continued with more felsic and explosive facies that were either erupted in a subaqueous or subglacial setting (members B and C). Next, the most extensive deposits were massive to crudely layered felsic volcaniclastic breccia, most likely of a subaqueous or subglacial origin consisting of hydrothermal explosion breccias or hyaloclastites, although they could also represent subaerial block and ash flows (member D). The uppermost clastic volcanics record a return to more mafic volcanism (member E). Overall, the progression of volcanism defines a magmatic system that is differentiating and becoming more felsic through time.

Matulka group.-The ooid grainstone and laminated siltstone and sandstone of the Matulka group were deposited during non-glacial conditions (table 3). Ferri and others (1999) suggested that the clastic units of the Matulka group could be correlated with coarse clastic rocks further north, and the rapid changes in facies of the associated units were due to block faulting related to extensional tectonism, consistent with syn-sedimentary alkalic volcanism. We propose that the ooid grainstone was deposited in an agitated carbonate bank or shoal. A high-energy subtidal depositional setting associated with tidal sand bars and/or a migrating barrier complex is needed to generate the ooids, and, in section A1419, the large rip up clasts of carbonate suggest storm or wave activity. The overlying finely laminated graded beds of the maroongreen siltstone display no evidence for storm or wave activity and could indicate an overall deepening of the basin. Finally, near the top, the renewed carbonate deposition and immature sandstone suggest a shallowing of the basin along with new proximal detrital input.

Unconformities. - Our stratigraphic data, map relationships, and age model imply two unconformities in the sequence. The first, between the Frog quartzite and the Gataga volcanics, is suggested by the sharp contact and the dramatic change in environment. For the Gataga volcanics, the depositional environment dramatically changes from a shallow environment with desiccation cracks of the Frog quartzite to the deeper water epiclastic volcanic deposits, basalt flows as well as the laminated siltstones and glacially influenced diamictite of the basal Gataga volcanics. This major change in depositional environments along with the sharp contact between the two suggests that there may be an uncertain amount of time missing.

Second, there is likely an unconformity with significant time missing between the Gataga volcanics and the Matulka group. The lack of similarity in the volcanic geochemistry between the Gataga volcanics and the Matulka group volcanics indicates that the Matulka group volcanics may be distinct from the Gataga volcanics and that there is an unconformity between them. The map relations and the apparent truncation of member $\mathrm{E}$ of the Gataga volcanics into carbonate of the Matulka group may also suggest an angular unconformity, or could merely reflect erosional features associated with the volcanics themselves or additional structures.

We propose that the Gataga volcanics and the volcanics of the Matulka group represent two separate rift-related volcanic events. 


\section{Discussion of Glacial Influence Within the Gataga Volcanics}

Volcaniclastic breccias, columnar jointing, basal and upper matrix supported diamictite units and interbedded units are consistent with volcanic influenced deposition in either a sub-aqueous environment involving higher energy debris flows or in a glaciomarine environment. The key question is whether the volcanic deposits indicate subaqueous or subglacial volcanism. Extensional tectonics can complicate interpretations, as rifting can create accommodation space and considerable relief that can aid in mass wasting and debris flows. Alternatively, rapid facies changes could be due to the heterogeneous nature of volcanic deposits and volcanic environments. Ideally, the presence of glacially striated or faceted clasts, or deposition on glacially scoured bedrock, can assist in distinguishing between glacial and non-glacial environments.

The best-documented intra-glacial and sub-glacial volcanoes are from Iceland and Antarctica. There, basaltic subglacial volcanoes display masses of pillow lavas followed by palagonitized breccias and volcaniclastic deposits (Werner and others, 1996; Skilling, 2009). Rhyolitic eruptions consist primarily of hyaloclastites and lava lobes followed by brecciated pumice and glass resulting from explosive activity and fragments of obsidian and stony rhyolite related to brecciated lobes (Mathews, 1947; Furnes and others, 1980; Cas and Wright, 1987). The Torfajökull volcanic complex, Iceland's largest rhyolite center is dominated by rhyolite erupted in subglacial and subaerial environments, with minor basaltic hyaloclastites and fluvioglacial sediments (Tuffen and others, 2001). Subglacial volcanism is distinguished by the following features: 1) dominance of breccias, with evidence for magma-water interaction (perlitized obsidian, blocky ash shards, matrix vesicles); 2) columnar jointing suggesting that many lava bodies in the sequence chilled against steeply inclined, sub-planar surfaces such as ice walls (Lescinsky and Sisson, 1998); 3) faceted clasts and a mud matrix consistent with a subglacial derivation (Tuffen and others, 2001); 4) lack of paleotopography which could have confined a non-glacial lake (Smellie and Skilling, 1994; Smellie and Hole, 1997); and 5) topographic features like flat-topped tuyas (McGarvie, 2009).

Glacial deposits are typically unsorted, angular, chemically immature and rarely contain clays. Glaciomarine deposits are commonly dominated by till sheets that form near the ice-grounding line when ice reaches a lake or sea and starts to melt, releasing glacial debris into the water. Till sheets are also associated with turbidites, submarine debris flows, and storm deposits (Eyles and others, 1985; Lonne, 1995; Wang and Hesse, 1996). Till sheet-debris flow facies associations can be difficult to distinguish from non-glacial submarine debris flows, or if there is significant volcanic debris, from volcanic lahars, a mass of flowing volcanic debris intimately mixed with water (Jerram and Petford, 2011). Additionally, lahars can entrain non-volcanic clasts and occur subaqueously, subaerially, or subglacially when subglacial eruptions cause the ice to melt and generate high water content (Cas and Wright, 1987; Jerram and Petford, 2011). Finally, large clasts can be transported long distances in icebergs and as the icebergs melt, the clasts fall to the sea floor and typically land in muds, becoming dropstones. Dropstones are associated with laminated mud (or other, shallower water deposits) (Thomas and Connell, 1985).

Diamictite unit of Member A.-The diamictite unit in member A occurs near the base of the volcanics, between beds of volcanic rocks. Outsized volcanic clasts, especially if they are pumice clasts, could be emplaced directly through airfall from a volcanic source, but this is an unlikely explanation for the polymict clasts we observed. In this case, the outsized clasts do not appear to be related to graded beds nor show evidence of imbrication, and some of the clasts are not locally sourced. The pale mature quartzite clasts could be from the Frog quartzite below, but the dark quartzite and the carbonate clasts have an uncertain origin. Many of the exotic clasts of 
unknown source display some amount of rounding that argues against the clasts having purely a magmatic source, such as lithic clasts or wall rock derived from the magma conduit. We suggest that the diamictite of member A is possibly a subglacial till sheet or lahar. However, we cannot rule out a marine debris flow interpretation, as direct indicators of glacial sedimentation such as glacial faceting and striating of clasts were not documented in this diamictite unit.

As the diamictite bed is within the stack of subaqueous volcanics, it is likely that the diamictite was deposited synchronously with local volcanism and that the dates on the volcanic rocks also provide ages for the formation of the associated diamictite units.

Diamictite and exotic clasts in member D. - Potential indicators of a glacial influence include exotic clasts such as the rounded granite clast near the base of Section A1419, as well as laminated siltstone and carbonate clasts. However, the dominant clast and matrix lithologies are volcanic and homogeneous, which suggests that any potential glacial influence was overwhelmed by the volcanic influence. Near the top of member $\mathrm{D}$, the thinly laminated volcanic beds could be indicative of airfall ashes and tuffs, ground or ash-cloud surge deposits, or epiclastic reworking of volcanically derived sediment. Additionally, within these units, the diamictite with a bed penetrating dropstone that deforms laminations further suggests a glaciogenic origin. However, in volcanic settings, dropstones of country rock or volcanic rocks can form as near vent ballistic blocks and bombs, particularly in phreatomagmatic eruptions (Cas and Wright, 1987). We neither observed bread-crust textures characteristic of volcanic bombs nor faceted or striated clasts to distinguish between these two depositional settings.

Taken together, we suggest the volcanic facies preserved at Gataga Mountain are similar to those described from sub-ice settings in Iceland and Antarctica (for example Mathews, 1947; Furnes and others, 1980; Cas and Wright, 1987; Smellie and Skilling, 1994; Smellie and Hole 1997; Tuffen and others, 2001) and are broadly consistent with eruption in a sub-ice to glacial influenced subaqueous setting below an ice shelf.

Preferred interpretation. - The early stage of the Gataga volcanics involves subsidence of the basin and mafic eruptions with evidence for early glacially influenced deposition but not for grounded ice. Near the end of this stage, mafic volcanism wanes but sedimentation continues before a switch to more intermediate volcanism. The second stage involves a transition to shallower explosive facies accompanied by associated intrusives. The last stage is marked by fragmented felsic volcaniclastic deposits, likely submarine to subglacial hyaloclastites, with increasing glacial influence up section. This was followed by a brief return to mafic volcanism.

Iron formation.-The return of iron formation to the sedimentary record is a distinctive characteristic of the Sturtian glaciation (Macdonald and others, 2010b; Cox and others, 2013) and has been previously documented in several other basal glaciogenic units of the Windermere Supergroup (Klein and Beukes, 1993; Macdonald and others, 2010a; Halverson and others, 2011; Cox and others, 2013, 2016; Baldwin and others, 2016). Neoproterozoic iron formation has classically been linked to Snowball Earth and the idea that ice cover would restrict ocean-atmosphere $\mathrm{O}_{2}$ exchange, leading to bottom-water stagnation (Kirschvink, 1992; Klein and Beukes, 1993). However, recent syn-Snowball ocean circulation models suggest that ocean mixing is just as vigorous during a Snowball glaciation as it is during ice-free times (Ashkenazy and others, 2013). Moreover, the classic model would predict that the iron formation should form during deglaciation when the ocean and atmosphere mixed and oxygenated runoff provided oxidants to drive insoluble Fe-oxide precipitation; however, iron formations are not restricted to the top of glacial deposits but instead tend to be associated with glaciation, localized in semi-restricted rift basins (Macdonald and others, 2013b; Cox and others, 2013). The stratigraphy and geochronology at Gataga 


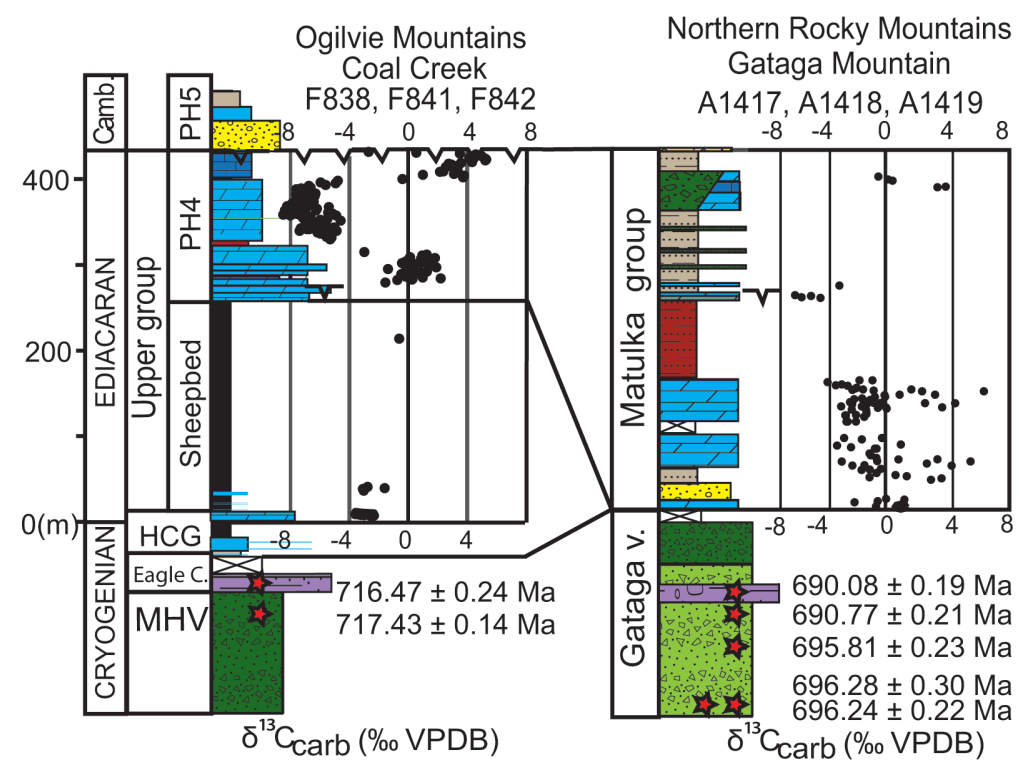

Fig. 10. Composite chemostratigraphy and regional correlations of the Gataga volcanics with strata in the Coal Creek inlier in northwestern Canada (Macdonald and others, 2013b). See figure 2 for lithology key. PH4 and PH5 are Ediacaran and Cambrian map units as described in Macdonald and others, 2013b and references therein. $\mathrm{HCG}=$ Hay Creek Group, Eagle $\mathrm{C}=$ Eagle Creek Formation, $\mathrm{MHV}=$ Mount Harper Volcanics.

Mountain suggest that iron formation was deposited during the Sturtian glaciation. The association of the iron formation with the Gataga volcanics is consistent with a volcanic, hydrothermal iron source (Cox and others, 2013, 2016) and the role of local restriction in rift basins providing protection from eddy mixing (Ashkenazy and others, 2013).

\section{Regional Correlations}

Regional equivalents of the Gataga volcanics include the broadly distributed massive diamictite and stratified glacial deposits with coarse-grained ice-rafted debris of the Rapitan Group in the Ogilvie Mountains (Eagle Creek Formation) (figs. 10 and 11), and the Mackenzie, and Wernecke Mountains (Mount Berg, Sayunei and Shezal) (fig. 11). In the Ogilvie Mountains, a glaciogenic origin for the Rapitan Group is confirmed by the presence of faceted and striated clasts, bed-penetrating dropstones, common outsized and exotic clasts and glacial push structures in the Eagle Creek Formation (Macdonald and others, 2010a; Macdonald and others, 2011; Strauss and others, 2014b). In the Mackenzie and Wernecke Mountains, the Rapitan Group depositional environment has been interpreted as a glacially influenced marine setting, based on the presence of lonestones, striated clasts, and till pellets in otherwise fine- to medium-grained turbiditic rocks (Young, 1976; Eisbacher, 1981, 1985). Additionally, the Rapitan Group contains jasper-hematite iron formation that can be as much as $100 \mathrm{~m}$ thick (Eisbacher, 1981; Yeo, 1981; Baldwin and others, 2016).

In the Ogilvie Mountains, the Eagle Creek Formation is underlain by the Mount Harper Volcanics. A rhyolite dome near the top of the volcanics was dated with CA-ID-TIMS U-Pb zircon at $717.43 \pm 0.14 \mathrm{Ma}$ and a tuff within the overlying diamictite was dated at $716.47 \pm 0.24 \mathrm{Ma}$ (Macdonald and others, 2010a). Although we broadly correlate the Gataga volcanics with the Sturtian glaciation, the presence of $707 \mathrm{Ma}$ 


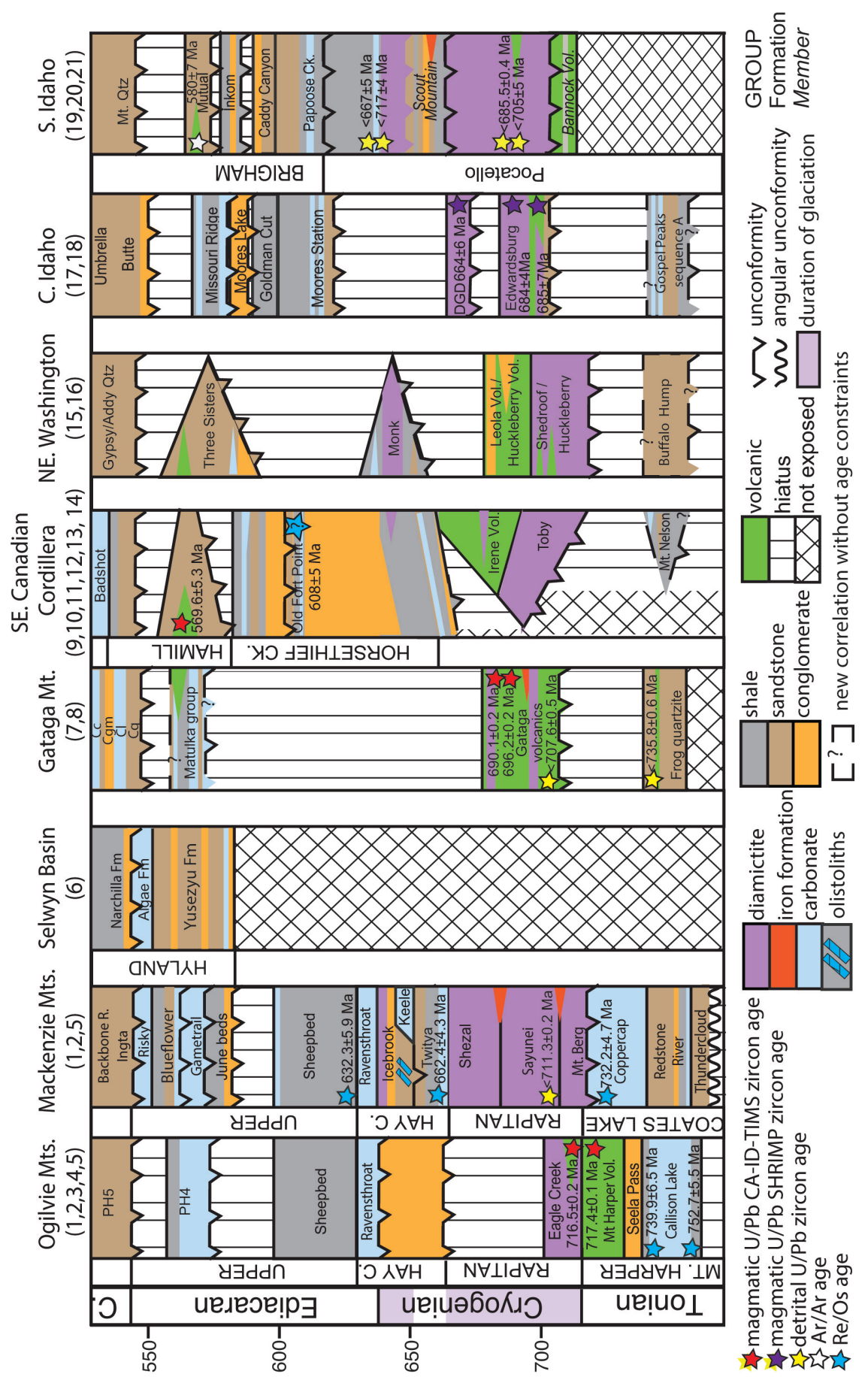

Fig. 11. Correlation chart of key Windermere Supergroup successions on the western margin of Laurentia. Schematic stratigraphy and age constraints are modified from: (1) Macdonald and others, 2010a; (2) Macdonald and others, 2013b; (3) Strauss and others, 2014a; (4) Strauss and others, 2015; (5) Rooney and others, 2014 and 2015; (6) Moynihan, 2014; (7) This study; (8) Ferri and others, 1999; (9) Warren, ms, 1997; (10) Kendall and others, 2004; (11) Devlin and Bond, 1988; (12) Aalto, 1971; (13) Colpron and others, 
detrital zircon near the base of member A suggests that much of the early stage of glaciation is missing and that the Gataga volcanics are not strictly correlative with the Mt. Harper Volcanics. This is also consistent with an unconformity at the base of the Gataga volcanics.

Farther south, near the British Columbia-Yukon border, Neoproterozoic strata outcrops near Toobally Lake and Pool Creek. At Toobally Lake, there are outcrops of the massive, orange weathering, mud matrix-supported glacial diamictite of the Toobally Formation as well as overlying alkali basalt tuffs and breccia (Pigage and MacNaughton, 2004; Pigage, 2006; Pigage, 2009). Samples were analyzed with laser ablation inductively coupled plasma mass spectrometry (LA-ICPMS), and two young zircons were isolated from the one sample from the Toobally Formation $(653.1 \pm 2.9$ Ma, $649.0 \pm 2.9$ Ma with $1 \sigma$ error, Pigage, 2009). However, these ages should be viewed critically since only two young zircon grains were isolated and U-Pb microbeam techniques are not always as precise and accurate as needed. Typical dates from $\mathrm{U}-\mathrm{Pb}$ microbeam techniques such as LA-ICPMS have $2 \sigma$ uncertainties that are about an order of magnitude larger than for ID-TIMS (Condon and Bowring, 2011), and although the dates from the two techniques usually overlap, in some cases the standard deviation of spot analysis date on a single zircon will not encompass the ID-TIMS date on that zircon (Schoene, 2014).

In the Pool Creek area, outcrops of pale quartz-rich sandstone and green argillite with volcanic clasts are exposed and appear to be intruded by the Pool Creek Syenite (Allen and others, 2001; Pigage, 2006; Pigage, 2009; MacNaughton and others, 2017). Some samples were analyzed with LA-ICPMS, but only one young zircon with large error was obtained from the argillite unit (654 \pm 25 Ma with $1 \sigma$ error- Pigage, 2009). Zircon fractions isolated from the Pool Creek Syenite underwent ID-TIMS (without chemical abrasion) and displayed very strange U-Th-Pb systematics, with very low $\mathrm{U}$ contents and very high Th contents (Pigage and Mortensen, 2004). In addition to the atypical $\mathrm{U}$ and $\mathrm{Th}$ concentrations, most of the zircon fraction analyses were scattered along the concordia rather than on it, likely reflecting the effects of post-crystallization Pb-loss (Pigage and Mortensen, 2004). The resulting U-Pb isotopic dating of zircon fractions from the different intrusive phases resulted in a cluster of ages of 640 to 650 Ma for the Pool Creek Syenite and associated dikes (Pigage and Mortensen, 2004). The Pool Creek Syenite is not known to intrude the Toobally Formation.

In general, the work on the Neoproterozoic strata in the Toobally Lake and Pool Creek area suffers from imprecise geochronology and poor exposure that limits conclusive interpretations of the stratigraphic relationships and regional correlations. The Toobally diamictite was suggested to be Marinoan in age as the preferred depositional age was $650 \mathrm{Ma}$ based on the detrital zircon LA-ICPMS ages (Pigage, 2009). Furthermore, the Toobally Formation was previously correlated with the Stelfox member of the Ice Brook Formation in the Mackenzie Mountains and with the Vreeland Formation to the south (see discussion below) based the stratigraphic position of the Toobally Formation beneath lower Cambrian strata and on the presence of lithological similarities. One such similarity was a parallel laminated dolostone, at least $20 \mathrm{~m}$ thick and low in the Toobally succession, with similarities to Marinoan cap carbonates (Pigage and MacNaughton, 2004). This dolostone was interpreted to be an olistolith as its bedding was dramatically different from the

Fig. 11 (continued). 2002; (14) Ross and others, 1995; (15) Brown and others, 1994; (16) Miller, 1994; (17) Lund and others, 2003; (18) Lund and others, 2010; (19) Fanning and Link, 2004; (20) Keeley and others, (2013); (21) Christie-Blick and Levy, 1989. Also highlighted are suggested durations for the Sturtian (717-662 Ma) and Marinoan (655-635 Ma) Snowball Earth glaciations. Dashed boxes around formations/ groups highlight interpretations that lack age constraints. 
regional dip of the Toobally Formation and folding was unlikely to cause the difference (Pigage and MacNaughton, 2004). No similar cap carbonate was observed to overlie the Toobally Formation (Pigage and MacNaughton, 2004; Pigage, 2009). It was argued that the absence of a cap carbonate might indicate non-deposition or erosion above the Toobally Formation (Pigage and MacNaughton, 2004). However, considering the uncertainty in the lithological correlations and in the LA-ICPMS ages, it is also possible that the Toobally diamictite and overlying volcanics are correlative with the Gataga volcanics.

To the south in the central Rocky Mountains, the Gataga volcanics sequence may be correlative with the Vreeland Formation, which has previously been assigned a Marinoan age (McMechan, 2000; Smith and others, 2011; McMechan, 2015). Although the Vreeland Formation was originally suggested to be correlative with the Sturtian glacial deposits (Slind and Perkins, 1966), it was revised to Marinoan following identification of a possible Marinoan-age cap carbonate, and broad mapping and stratigraphic relationships integrated with pre-existing age constraints. Particularly, the Vreeland Formation is overlain by a limestone cap carbonate as well as laminated dolomite olistoliths with negative $\delta^{13} \mathrm{C}_{\text {carb }}$ values that were correlated with Marinoan cap carbonates (McMechan, 2000). Both the Sturtian and Marinoan cap carbonates display negative $\delta^{13} \mathrm{C}_{\text {carb }}$ values making it harder to distinguish between them. Furthermore, in some cases the strata between the Sturtian glacial deposits and Marinoan cap carbonate is only a few tens of meters thick (Macdonald and others, 2010a) or absent (Macdonald and others, 2013a), allowing the Marinoan cap carbonate to closely overlie Sturtian glacial deposits. However, the Marinoan cap carbonate tends to be dolostone throughout the Cordillera (Macdonald and others, 2013a, 2013b), whereas the $c a .660 \mathrm{Ma}$ Sturtian cap carbonate is limestone (Rooney and others, 2014). Also, olistoliths have been documented in Cryogenian strata between the Sturtian and the Marinoan glaciations (Eisbacher, 1978; Aitken, 1991).

The Vreeland Formation is suggested to preserve lateral stratigraphic continuity of facies (for example McMechan, 2000), while the Rapitan shows evidence of syn-sedimentary tectonism (Eisbacher, 1981), leading to the suggestion that the Vreeland deposition post-dates major basal Windermere tectonic-activity (McMechan, 2000; Smith and others, 2011; McMechan, 2015). However, lower portions of the Vreeland Formation display facies changes from diamictite to mixed siliciclastics of the Paksumo Formation, while the upper strata changes facies to grit and argillite of the lower McKale Formation (McMechan, 2015). These observations are more consistent with Sturtian-age diamictites in the northern Cordillera (Eisbacher, 1981). In addition, the Vreeland diamictite expands to over a kilometer in thickness (McMechan, 2015), and Sturtian-age diamictites are commonly thick in the Cordillera whereas Marinoan diamictites are often thin or absent (for example Eisbacher, 1978; Macdonald and others, 2013a).

The Vreeland limestone cap and carbonate olistoliths have been correlated with the Old Fort Point Formation by Smith and others (2014) and associated Re-Os isochron date of $607.8 \pm 4.7 \mathrm{Ma}$ interpreted as a Marinoan termination age (Kendall and others, 2004). If correct, this could be used to argue for a Marinoan or later Ediacaran age for the Vreeland Formation. However, this Re-Os age is from an isolated outcrop that is not in direct contact with the underlying Marinoan-age glacial deposits or distinctive cap carbonate (Kendall and others, 2004; Rooney and others, 2015). Additionally, the termination of the Marinoan glaciation is robustly dated farther north, where a Re-Os age of 632.3 \pm 5.9 Ma was obtained from less than a meter above the Marinoan-age Ravensthroat cap carbonate (Rooney and others, 2015).

Finally, although the Vreeland Formation lacks direct geochronological constraints to support a Marinoan age, that correlation was supported by its inferred 
height within the Windermere succession and previous age estimates for the Sturtian diamictites. The Vreeland Formation overlies hundreds of meters of stratigraphy and non-conformably overlies the 728 Ma Deserters Range Gneiss. This combined with previous $c a$. $770 \mathrm{Ma}$ estimates for the Sturtian glaciation led authors to suggest that Vreeland was much younger than the Toby and Rapitan diamictites, and thus must correspond to the younger glacial interval, not the older (Hein and McMechan, 1990). Given updated age constraints (for example Macdonald and others, 2010; Strauss and others, 2014; Rooney and others, 2015), this argument is unfounded. Having reviewed the existing literature on the stratigraphy and map relationships combined with new age observations and constraints on the Sturtian glaciation farther north, we suggest that the Vreeland Formation is more likely correlative with the Gataga Mountain sequence, the Rapitan Group and the Sturtian glaciation.

In southern British Columbia, we correlate the Gataga volcanics with the undated glaciogenic Toby Formation and the localized rift-related mafic volcanic rocks of the Irene Formation (fig. 11). The Toby Formation is gradationally overlain by mafic basalt flows, basalt breccia, and pillow basalts of the Irene Volcanics (Brown and others 1994; Warren, ms, 1997). The pillows are observed to have chilled margins and minor intrapillow micrite. There are also mafic tuff, tuff breccia and hyaloclastic. At the top of the Irene Volcanics occurs a $100 \mathrm{~m}$ thick conglomerate (Brown and others 1994). In Washington State, these units are likely correlative with the Huckleberry Formation, the Shedroof Conglomerate and Leola Volcanics (Miller, 1994).

Further south, we correlate the Gataga volcanics with the Edwardsburg Formation and the Bannock Volcanic Member of the Pocatello Formation of southeastern Idaho (Lund and others, 2003; Fanning and Link, 2004; Keeley and others, 2013). Although both the Edwardsburg and Pocatello formations include poorly sorted, matrixsupported diamictites, a glacial origin for the Edwardsburg Formation has not been established. The Edwardsburg Formation has been dated by SHRIMP methods on zircon to $685.6 \pm 7 \mathrm{Ma}$ (Lund and others, 2003). A glacial origin has been demonstrated for the Scout Mountain Member of the Pocatello Formation, and epiclastic deposits at Oxford Mountain have been dated with CA-ID-TIMS at $685.5 \pm 0.4 \mathrm{Ma}$, providing a maximum depositional age constraint for the upper portion of the glacial succession (Keeley and others, 2013).

We attempted to constrain the age of the Matulka group and associated volcanic rocks using carbon isotope chemostratigraphy, but this was hindered by the lack of definitive trends, the dominance of scatter, and the highly altered nature of the carbonates. Based on the data from the less recrystallized carbonates (A1417), we compared the Matulka group with strata in the Coal Creek inlier, Ogilvie Mountains (fig. 10), which also overlie volcanic rocks (Macdonald and others, 2010, 2013b). Using this comparison we suggest that the Matulka group could be correlative with PH4 (Upper group) in the Coal Creek inlier. Both groups display broadly similar stratigraphy and correlative carbon isotope trends, with negative excursions in the middle of the section, followed by positive values around +4 permil and then back towards 0 permil at the top. In the Mackenzie Mountains the Sheepbed Formation, which underlies PH4 in the Coal Creek inlier, has been dated to $632.3 \pm 5.9 \mathrm{Ma}$ (Re-Os from Rooney and others, 2015), while strata correlated with PH4 have been suggested to be $c a .580$ to $560 \mathrm{Ma}$ due to preserved Ediacaran biota (Macdonald and others, $2013 \mathrm{~b})$. Thus, we suggest that the Matulka group may be younger than $630 \mathrm{Ma}$, and likely close to $c a$. 580 to $560 \mathrm{Ma}$. This is also consistent with our suggested unconformity between the Matulka group and the underlying Gataga volcanics.

In addition to the strata exposed in the Ogilvie Mountains, the EdiacaranCambrian Hyland Group is exposed in the Selwyn Basin in the southern Yukon, where there is a similar sequence of carbonate followed by maroon mudstone and additional 
carbonate and siliciclastic strata (fig. 11). The Hyland Group consists of the Yusezyu, Algae, and Narchilla formations (Colpron, 2012). The Yusezyu Formation is dominated by brownish-gray shale, sandstone and grit (pebbly sandstone), becoming calcareous near top of formation (Colpron, 2012). The basal Algae Formation includes 250 to $350 \mathrm{~m}$ of pale to dark gray, thinly to medium-bedded cliff-forming limestone and dolostone with ooids, intraclasts, cross beds and minor chert. There is an irregular erosional surface between it and the overlying Cambrian Narchilla Formation. The Narchilla Formation is an almost $1 \mathrm{~km}$ thick deformed sequence of dominantly fine-grained clastic rocks. In some localities, the Narchilla Formation has been divided into two members, one dominated by gray siltstone and shale, and one dominated by maroon and green argillite with a distinct contact between them (Cecile, 2000). In other localities, the Narchilla Formation is observed to have a highly variable basal siliciclastic to conglomeratic-grit member overlain by a thin-bedded bioturbated green, mauve or maroon mudstone, siltstone, and shale, with some sandstone-rich intervals (Moynihan, 2014). Lithological correlations would suggest that the basal Matulka group could be correlative with the Algae Formation, and our maroon-siliciclastic unit is correlative with the Narchilla Formation, suggesting that the Matulka group could be as young as Cambrian.

Further south, we correlate the Matulka group with the Hamill Group in the southeast Canadian Cordillera (Devlin, 1989; Colpron and others, 2002), the Three Sisters Formation in northeast Washington (Miller, 1994), and the Missouri Ridge and Mutual/Inkom formations in Idaho (Link and others, 1993; Christie-Blick, ms, 1997; Lund and others, 2003). Most of these units include carbonates and siliciclastics, as well as volcanic deposits in two cases (fig. 11). Our suggested correlation of the Matulka group with later Ediacaran age strata and the proposed double-rift is influenced by the known existence of Hamill Group volcanics already dated to Ediacaran time.

\section{Rift History}

Although our new data do not resolve uncertainties related to the paleogeography and identity of the conjugate continent, or the geometry of rifting along the western margin of Laurentia, it does bear on the timing and number of rift events. As rifting is connected to alkalic igneous rocks and coarse sedimentation, more data on those sequences assist in understanding those connections. Several authors favor discrete rift events rather than protracted rifting, such as Colpron and others (2002) who suggested that there were two stages for the rifting leading to continent separation, with the first stage of rifting at $750 \mathrm{Ma}$ to $700 \mathrm{Ma}$ and a second stage of rifting at 600 to 560 Ma. Our data, along with recent geochronology from Yukon and Idaho suggest that most of the rift-related magmatism occurred between 720 to $680 \mathrm{Ma}$ (Macdonald and others, 2010a; Keeley and others, 2013). This appears to be distinct from the $c a .775 \mathrm{Ma}$ magmatism associated with the Gunbarrel LIP (Harlan and others, 2003; Milton and others, 2014) and the subsequent 775 to 717 Ma subsidence in the ChUMP basins and equivalents in Canada (Chuar, Uinta Mountain, Pahrump, Coates Lake, and Mt. Harper groups).

Our new ages for the Gataga volcanics suggest a $<707$ Ma maximum depositional age for the basal Gataga volcanics and include 696 to 690 Ma magmatic ages for upper felsic Gataga volcanics. Furthermore, the volcanic and zircon geochemistry suggest anorogenic rift type volcanism.

When considering this rift stage and the Gataga data in relation to other sections along the margin (fig. 11), rift related volcanism in the northern Coal Creek inlier of the Yukon occurred predominantly just prior to $c a$. $717 \mathrm{Ma}$, perhaps triggered by the Franklin LIP. We suggest that the Gataga volcanism is part of a pulse of $c a$. 710 to 680 Ma magmatism further south along the western margin. In central Idaho, the mixed 
diamictite and volcanics of the Edwardsburg have a basal $685 \pm 7$ Ma magmatic age (SHRIMP U/Pb zircon), and an upper $684 \pm 4 \mathrm{Ma}$ magmatic age (SHRIMP U/Pb zircon) (Lund and others, 2003). Also, in southern Idaho, within the lower Scout Mountain member of the Pocatello formation, zircon from reworked tuffs have been dated to $<685.5 \pm 0.4 \mathrm{Ma}$ (detrital CA-ID-TIMS U/Pb zircon; Keeley and others, 2013), and <705 \pm 5 Ma (detrital SHRIMP U/Pb zircon; Keeley and others, 2013). Although these deposits are not primary, the zircon provenance does appear to be proximal (Keeley and others, 2013). In addition, near the top there is a $717 \pm 4 \mathrm{Ma}$ (SHRIMP U/Pb zircon) age on a porphyritic silicic clast that has been used to suggest that regional volcanism in Idaho lasted $\sim 30$ million years (Fanning and Link, 2004). An alternative interpretation is that the clast may have been transported long distances, as might be expected during prolonged glacial periods.

There may be an additional pulse of younger magmatism that is hinted at in overlying units, with a $664 \pm 6$ Ma magmatic age (SHRIMP U/Pb zircon; Lund and others, 2010) on a tuff within an upper diamictite in Central Idaho, and in southern Idaho, a $<667 \pm 5$ detrital age (SHRIMP U/Pb zircon concordia; Fanning and Link, 2004) from a reworked tuff within an upper sandstone.

Geochemically distinct volcanism in the non-glacial Matulka group may be related to this or a younger episode of rifting. We propose that the Matulka group is broadly correlative with unit PH4 in the Yukon, and with the Hamill-Gog Group in southern British Columbia, which contains volcanics dated with U-Pb TIMS on zircon at $569.6 \pm$ 5.3 Ma (Colpron and others, 2002). Additionally, in the Gataga area, the volcanics in the Matulka group are overlain by a Cambrian conglomerate unit (Cgm) that is potentially rift related, which suggests that extension may have been active from the Ediacaran to earliest middle Cambrian.

\section{Cryogenian Glaciation}

Existing geochronological constraints on the Sturtian glaciation from the Rapitan Group in the Ogilvie Mountains demonstrate that it initiated by $c a$. $716 \mathrm{Ma}$ (Macdonald and others, 2010a). If the Sturtian glaciation lasted $>55$ million years (Rooney and others, 2014, 2015), then the diamictite units within the Gataga volcanics likely were deposited during the Sturtian glaciation. The volcanic stratigraphy of the Gataga volcanics is consistent with eruption in sub-glacial conditions, with evidence for $c a .690$ Ma glaciation in the Gataga area including exotic clasts, diamictite, and dropstones. The detrital age from the Frog quartzite gives a maximum age constraint of $<735 \mathrm{Ma}$ on the onset of the glaciation in the area. Additionally, we provide a maximum age constraint at the base of Member A of $<707 \mathrm{Ma}$, about 10 meters below the basal diamictite, but above the contact between the Frog quartzite and the Gataga volcanics.

Near the border of Yukon and the Northwest Territories, a detrital zircon CA-ID-TIMS U-Pb date of 711.34 \pm 0.24 Ma was reported from the Sayunei Formation and used to argue that onset of the Sturtian glaciation was not synchronous on the Laurentian margin (Baldwin and others, 2016). However, the sample was collected at the top of the Sayunei Formation from a cross-bedded hematitic siltstone beneath a thin iron formation, just below the transition from the Sayunei to the Shezal Formation (Baldwin and others, 2016). In the measured section from which they collected this sample from, there was about $200 \mathrm{~m}$ of Sayunei Formation below the sample, but the base of the section was not exposed. Typically, the Sayunei Formation is several hundred meters thick and sits above an unconformity of unknown duration, likely related in part to glacio-eustatic sea level fall and in part to syn-depositional faulting (Eisbacher, 1981, 1983). Thus, the $711.33 \pm 0.25$ Ma date is a maximum age constraint for the top of the Sayunei Formation and base of Shezal Formation, and is consistent with synchronous onset of the Sturtian glaciation by $c a$. 716.5 Ma. Similarly, for the Gataga volcanics, we suggest that there is an unconformity with an uncertain amount 
of time missing at the base, and the only maximum constraint we have on the onset of glaciation is the $<735 \mathrm{Ma}$ detrital zircon constraint from the top of the non-glacial Frog Quartzite.

\section{CONCLUSIONS}

Here we report new ages for the Gataga volcanics with a $<707$ Ma maximum depositional age for the basal Gataga volcanics and 696 to 690 Ma eruptive ages for upper felsic Gataga volcanics. Evidence for $c a$. $690 \mathrm{Ma}$ glaciation includes exotic clasts, diamictite, and dropstones suggestive of sub-glacial volcanism during the Sturtian Snowball Earth glaciation. Finally, the proposed unconformity and correlation of the Matulka group indicate that there could be significant time missing between the Gataga volcanics and the Matulka group. Thus we suggest that there are two episodes of extension, basin formation, and magmatism recorded at Gataga Mountain. The first episode includes the Gataga volcanics and associated volcanism, and is part of southward propagating extension 710 to $680 \mathrm{Ma}$ along the western margin of Laurentia. This volcanism is tentatively syn-glacial in the Gataga area. A second occurrence of geochemically distinct anorogenic/rift-related volcanic rocks occurs in the non-glacial Matulka group, which we correlate with $c a .570$ Ma volcanism and basin formation along the margin.

\section{ACKNOWLEDGMENTS}

Fieldwork was supported by NSF SGP EAR-1148058. We thank the Kaska Dena First Nations and BC Parks for access to the field area in Dune Za Keyih Provincial Park and Protected Area. We thank Jim Crowley, Vince Isakson and Marion Lytle for help at the Boise State University Isotope Geology Laboratory; Debbie Pierce, Sarah Dendy, Sasha Breus and Camille Dwyer for providing assistance and training in the geochronology sample preparation process; Dan Schrag and Sarah Manley for use and assistance running carbon and oxygen isotope data in the Harvard University Geochemical Paleooceanography lab; and Emily Smith, Blake Hodgin, Uyanga Bold, and Jocelyn Fuentes for helpful discussions. We thank Margot McMechan and Gerry Ross for constructive reviews and Associate Editor David Evans for comments on this manuscript.

\section{REFERENCES}

Aalto, R. K., 1971, Glacial marine sedimentation and stratigraphy of the Toby Conglomerate (Upper Proterozoic), southeastern British Columbia, northwestern Idaho and northeastern Washington: Canadian Journal of Earth Sciences, v. 8, n. 7, p. 753-787, https://doi.org/10.1139/e71-073

Aitken, J. D., 1991, Two late Proterozoic glaciations, Mackenzie mountains, northwestern Canada: Geology, v. 19, n. 5, p. 445-448, https://doi.org/10.1130/0091-7613(1991) 019<0445:TLPGMM >2.3.CO;2

- 1993, Tectonic evolution and basin history, in Stott, D. E., and Aitken, J. D., editors, Sedimentary Cover of the North American Craton in Canada: Geological Survey of Canada, Geology of Canada, n. 5, p. 483-504, https://doi.org/10.1130/DNAG-GNA-D1.483

Allen, C. M., and Campbell, I. H., 2012, Identification and elimination of a matrix-induced systematic error in LA-ICP-MS ${ }^{206} \mathrm{~Pb} /{ }^{238} \mathrm{U}$ dating of zircon: Chemical Geology, v. 332-333, p. 157-165, https://doi.org/ 10.1016/j.chemgeo.2012.09.038

Allen, T. L., Pigage, L. C., and MacNaughton, R. B., 2001, Preliminary geology of the Pool Creek map area $(95 \mathrm{C} / 5)$, southeastern Yukon, in Emond, D. S., and Weston, L. H., editors, Yukon Exploration and Geology 2000: Exploration and Geological Services Division, Yukon, Indian and Northern Affairs Canada, p. 53-72

Armin, R. A., and Mayer, L., 1983, Subsidence analysis of the Cordilleran miogeocline: Implications for timing of late Proterozoic rifting and amount of extension: Geology, v. 11, n. 12, p. 702-705, https:/ / doi.org/10.1130/0091-7613(1983)11<702:SAOTCM>2.0.CO;2

Ashkenazy, Y., Gildor, H., Losch, M., Macdonald, F. A., Schrag, D. P., and Tziperman, E., 2013, Dynamics of a Snowball Earth ocean: Nature, v. 495, n. 7439, p. 90-93, https://doi.org/10.1038/nature11894

Baldwin, G. J., Turner, E. C., and Kamber, B. S., 2016, Tectonic controls on distribution and stratigraphy of the Cryogenian Rapitan iron formation, northwestern Canada: Precambrian Research, v. 278, p. 303-322, https://doi.org/10.1016/j.precamres.2016.03.014

Bond, G. C., and Kominz, M. A., 1984, Construction of tectonic subsidence curves for the early Paleozoic 
miogeocline, southern Canadian Rocky Mountains: Implications for subsidence mechanisms, age of breakup, and crustal thinning: Geological Society of America Bulletin, v. 95, n. 2, p. 155, https://doi.org/ 10.1130/0016-7606(1984) 95<155:COTSCF>2.0.CO;2

Bond, G. C., Christie-Blick, N., Kominz, M. A., and Devlin, W. J., 1985, An Early Cambrian rift to post-rift transition in the Cordillera of western North America: Nature, v. 315, n. 6022, p. 742-746, https:// doi.org/10.1038/315742a0

Bowring, S. A., Schoene, B., Crowley, J. L., Ramezani, J., and Condon, D. J., 2006, High-precision U-Pb zircon geochronology and the stratigraphic record: Progress and promise: The Paleontological Society Papers, v. 12, p. 25, https://doi.org/10.1017/S1089332600001339

Brady, P. V., and Gislason, S. R., 1997, Seafloor weathering controls on atmospheric $\mathrm{CO}_{2}$ and global climate: Geochimica et Cosmochimica Acta, v. 61, n. 5, p. 965-973, https://doi.org/10.1016/S00167037(96) 00385-7

Brown, D. A., Doughty, P. T., and Stinson, P., 1994, Preliminary geology of the Creston map area, southeastern British Columbia (82F/2): Geological Fieldwork Paper 1995-1.

Calver, C. R., Crowley, J. L., Wingate, M. T. D., Evans, D. A. D., Raub, T. D., and Schmitz, M. D., 2013 , Globally synchronous Marinoan deglaciation indicated by U-Pb geochronology of the Cottons Breccia, Tasmania, Australia: Geology, v. 41, n. 10, p. 1127-1130, https:/ /doi.org/10.1130/G34568.1

Cas, R. A. F., and Wright, J. V., 1987, Volcanic Successions, Modern and Ancient: A Geological Approach to Processes, Products and Successions, 528 p.

Cawood, P. A., 2005, Terra Australis Orogen: Rodinia breakup and development of the Pacific and Iapetus margins of Gondwana during the Neoproterozoic and Paleozoic: Earth-Science Reviews, v. 69, n. 3-4, p. 249-279, https://doi.org/10.1016/j.earscirev.2004.09.001

Cecile, M. P., and Norford, B. S., 2000, Geology of the northeastern Niddery Lake map area, east-central Yukon and adjacent Northwest Territories: Geological Survey of Canada, Bulletin \# 553, https:/ /doi.org/ $10.4095 / 211664$

Cecile, M. P., Morrow, D. W., and Williams, G. K., 1997, Early Paleozoic (Cambrian to Early Devonian) tectonic framework, Canadian Cordillera: Bulletin of Canadian Petroleum Geology, v. 45, n. 1, p. 54-74

Christie-Blick, N., ms, 1997, Neoproterozoic Sedimentation and Tectonics in West-Central Utah: Brigham Young University Geology Studies, Ph. D. thesis, 30 p.

Christie-Blick, N., and Levy, M., 1989, Concepts of sequence stratigraphy, with examples from strata of late Proterozoic and Cambrian age in the western United States, in Christie-Blick, N., and Levy, M., editors, Late Proterozoic and Cambrian Tectonics, Sedimentation and Record of Metazoan Radiation in the Western United States (28th International Geological Congress Field Trip Guidebook T331): Washington, D. C., American Geophysical Union, p. 23-37, https://doi.org/10.1029/FT331p0023

Colpron, M., 2012, Preliminary observations on the geology of the Rackla belt, Mount Ferrell map area (NTS 106C /3), central Yukon, in MacFarlane, K. E., and Sack, P. J., editors, Yukon Exploration and Geology 2011: Yukon Geological Survey, p. 27-43.

Colpron, M., Logan, J. M., and Mortensen, J. K., 2002, U-Pb zircon age constraint for late Neoproterozoic rifting and initiation of the lower Paleozoic passive margin of western Laurentia: Canadian Journal of Earth Sciences, v. 39, n. 2, p. 133-143, https://doi.org/10.1139/E01-069

Condon, D. J., and Bowring, S. A., 2011, A user's guide to Neoproterozoic geochronology, in Arnaud, E., Shields-Zhou, G., and Halverson, G. P., editors, The Geological Record of Neoproterozoic Glaciations: Geological Society of London Memoir, v. 36, n. 1, p. 135-149, https://doi.org/10.1144/M36.9

Condon, D., Zhu, M., Bowring, S., Wang, W., Yang, A., and Jin, Y., 2005, U-Pb ages from the Neoproterozoic Doushantuo Formation, China: Science, v. 308, n. 5718, p. 95-98, https://doi.org/10.1126/ science. 1107765

Condon, D. J., Schoene, B., McLean, N. M., Bowring, S. A., and Parrish, R. R., 2015, Metrology and traceability of U-Pb isotope dilution geochronology (EARTHTIME Tracer Calibration Part I): Geochimica et Cosmochimica Acta, v. 164, p. 464-480, https:/ / doi.org/10.1016/j.gca.2015.05.026

Cox, G. M., Halverson, G. P., Minarik, W. G., Le Heron, D. P., Macdonald, F. A., Bellefroid, E. J., and Strauss, J. V., 2013, Neoproterozoic iron formation: An evaluation of its temporal, environmental and tectonic significance: Chemical Geology, v. 362, p. 232-249, https://doi.org/10.1016/j.chemgeo.2013.08.002

Cox, G. M., Halverson, G. P., Poirier, A., Le Heron, D., Strauss, J. V., and Stevenson, R., 2016, A model for Cryogenian iron formation: Earth and Planetary Science Letters, v. 433, p. 280-292, https://doi.org/ 10.1016/j.epsl.2015.11.003

Crittenden, M. D., Jr., Christie-Blick, N., and Link, P. K., 1983, Evidence for two pulses of glaciation during the late Proterozoic in northern Utah and southeastern Idaho: Geological Society of America Bulletin, v. 94, n. 4, p. 437-450, https://doi.org/10.1130/0016-7606(1983)94<437:EFTPOG >2.0.CO;2

Dalrymple, R. W., and Narbonne, G. M., 1996, Continental slope sedimentation in the Sheepbed Formation (Neoproterozoic, Windermere Supergroup), Mackenzie Mountains, NWT: Canadian Journal of Earth Sciences, v. 33, n. 6, p. 848-862, https://doi.org/10.1139/e96-064

Dalziel, I. W., 1997, OVERVIEW: Neoproterozoic-Paleozoic geography and tectonics: Review, hypothesis, environmental speculation: Geological Society of America Bulletin, v. 109, n. 1, p. 16-42, https:// doi.org/10.1130/0016-7606(1997) 109<0016:ONPGAT>2.3.CO;2

Davydov, V. I., Crowley, J. L., Schmitz, M. D., and Poletaev, V. I., 2010, High-precision U-Pb zircon age calibration of the global Carboniferous time scale and Milankovitch-band cyclicity in the Donets Basin, eastern Ukraine: Geochemistry, Geophysics, Geosystems, v. 11, n. 2, https://doi.org/10.1029/ 2009GC002736

Dehler, C. M., Fanning, C. M., Link, P. K., Kingsbury, E. M., and Rybczynski, D., 2010, Maximum depositional age and provenance of the Uinta Mountain Group and Big Cottonwood Formation, northern Utah: Paleogeography of rifting western Laurentia: Geological Society of America Bulletin, v. 122, n. 9-10, p. 1686-1699, https://doi.org/10.1130/B30094.1 
Denyszyn, S. W., Halls, H. C., Davis, D. W., and Evans, D. A. D., 2009a, Paleomagnetism and U-Pb geochronology of Franklin dykes in High Arctic Canada and Greenland: A revised age and paleomagnetic pole constraining block rotations in the Nares Strait region: Canadian Journal of Earth Sciences, $\mathrm{v}$. 46, n. 9, p. 689-705, https://doi.org/10.1139/E09-042

Denyszyn, S. W., Davis, D. W., and Halls, H. C., 2009b, Paleomagnetism and U-Pb geochronology of the Clarence Head dykes, Arctic Canada: Orthogonal emplacement of mafic dykes in a large igneous province: Canadian Journal of Earth Sciences, v. 46, n. 3, p. 155-167, https://doi.org/10.1139/E09-011

Devlin, W. J., 1989, Stratigraphy and sedimentology of the Hamill Group in the northern Selkirk Mountains, British Columbia: Evidence for latest Proterozoic - Early Cambrian extensional tectonism: Canadian Journal of Earth Sciences, v. 26, n. 3, p. 515-533, https://doi.org/10.1139/e89-044

Devlin, W. J., and Bond, G. C., 1988. The initiation of the early Paleozoic Cordilleran miogeocline: Evidence from the uppermost Proterozoic-Lower Cambrian Hamill Group of southeastern British Columbia: Canadian Journal of Earth Sciences, v. 25, n. 1, p. 1-19, https://doi.org/10.1139/e88-001

Edwards, B., Russell, J., and Anderson, R., 2002, Subglacial, phonolitic volcanism at Hoodoo Mountain volcano, northern Canadian Cordillera: Bulletin of Volcanology, v. 64, n. 3-4, p. 254-272, https:// doi.org/10.1007/s00445-002-0202-9

Eisbacher, G. H., 1978, Re-definition and Subdivision of the Rapitan Group, Mackenzie Mountains: Geological Survey of Canada, Paper 77-35, 21 p., https://doi.org/10.4095/103527

- 1981, Sedimentary tectonics and glacial record in the Windermere Supergroup, Mackenzie Mountains, northwestern Canada: Geological Survey of Canada Paper 80-27, 40 p., https:/ /doi.org/10.4095/ 119453

1983, Devonian-Mississippian sinistral transcurrent faulting along the cratonic margin of western North America: A hypothesis: Geology, v. 11, n. 1, p. 7-10, https://doi.org/10.1130/00917613(1983) $11<7$ :DSTFAT > 2.0.CO;2

- 1985, Late Proterozoic rifting, glacial sedimentation, and sedimentary cycles in the light of Windermere deposition, western Canada: Palaeogeography, Palaeoclimatology, and Palaeoecology, v. 51, n. 1-4, p. 231-254, https://doi.org/10.1016/0031-0182(85)90087-2

Evans, D. A. D., 2009, The palaeomagnetically viable, long-lived and all-inclusive Rodinia supercontinent reconstruction: Journal of the Geological Society of London, Special Publications, v. 327, n. 1, p. 371-404, https://doi.org/10.1144/SP327.16

2013, Reconstructing pre-Pangean supercontinents: Geological Society of America Bulletin, v. 125, n. 11-12, p. 1735-1751, https://doi.org/10.1130/B30950.1

Evans, D. A. D., and Raub, T. D., 2011, Neoproterozoic glacial palaeolatitudes: A global update: Geological Society, London, Memoirs, v. 36, n. 1, p. 93-112, https://doi.org/10.1144/M36.7

Evenchick, C. A., 1988, Stratigraphy, metamorphism, structure, and their tectonic implication in the Sifton and Deserters Ranges, Cassiar and northern Rocky mountains, northern British Columbia: Bulletin of the Geological Survey of Canada, Bulletin, v. 376, 90 p., https://doi.org/10.4095/125164

Eyles, C. H., Eyles, N., and Miall, A. D., 1985, Models of glaciomarine sedimentation and their application to the interpretation of ancient glacial sequences: Palaeogeography, Palaeoclimatology, Palaeoecology, v. 51, n. 1-4, p. 15-84, https://doi.org/10.1016/0031-0182(85)90080-X

Eyster, A. E., Fu, R. F., Strauss, J. V., Weiss, B. P., Roots, C. F., Halverson, G. P., Evans, D. A. D., and Macdonald, F. A., 2017, Paleomagnetic evidence for a large rotation of the Yukon Block relative to Laurentia: Implications for a low-latitude Sturtian Glaciation and the break-up of Rodinia: Geological Society of America Bulletin, v. 129, n. 1-2, p. 38-58, https://doi.org/10.1130/B31425.1

Fanning, C. M., and Link, P., 2004, U-Pb SHRIMP ages of Neoproterozoic (Sturtian) glaciogenic Pocatello Formation, southeastern Idaho: Geology, v. 32, n. 10, p. 881, https://doi.org/10.1130/G20609.1

Ferri, F., Rees, C., Nelson, J., and Legun, A., 1999, Geology and Mineral Deposits of the Northern Kechika Trough between Gataga River and the 60th Parallel: Geological Survey Branch, Mineral Resources Division, British Columbia Ministry of Energy and Mines Bulletin 107, 122 p.

Fu, X., Zhang, S., Li, H., Ding, J., Li, H., Yang, T., Wu, H., Yuan, H., and Lv, J., 2015, New paleomagnetic results from the Huaibei Group and Neoproterozoic mafic sills in the North China Craton and their paleogeographic implications: Precambrian Research, v. 269, p. 90-106, https://doi.org/10.1016/ j.precamres.2015.08.013

Furnes, H., Fridleifsson, I. B., and Atkins, F. B., 1980, Subglacial volcanics-On the formation of acid hyaloclastites: Journal of Volcanology and Geothermal Research, v. 8, n. 1, p. 95-110, https://doi.org/ 10.1016/0377-0273(80)90009-8

Gabrielse, H., 1972, Younger Precambrian of the Canadian Cordillera: American Journal of Science, v. 272, n. 6, p. 521-536, https://doi.org/10.2475/ajs.272.6.521

Goddéris, Y., Donnadieu, Y., Nédélec, A., Dupré, B., Dessert, C., Grard, A., Ramstein, G., and Francois, L. M., 2003, The Sturtian 'snowball'glaciation: Fire and ice: Earth and Planetary Science Letters, v. 211, n. 1-2, p. 1-12, https://doi.org/10.1016/S0012-821X(03)00197-3

Halverson, G. P., Poitrasson, F., Hoffman, P. F., Nédélec, A., Montel, J. M., and Kirby, J., 2011, Fe isotope and trace element geochemistry of the Neoproterozoic syn-glacial Rapitan iron formation: Earth and Planetary Science Letters, v. 309, n. 1-2, p. 100-112, https://doi.org/10.1016/j.epsl.2011.06.021

Harlan, S. S., Heaman, L., LeCheminant, A. N., and Premo, W. R., 2003, Gunbarrel mafic magmatic event: A key 780 Ma time marker for Rodinia plate reconstructions: Geology, v. 31, n. 12, p. 1053-1056, https://doi.org/10.1130/G19944.1

Heaman, L. M., LeCheminant, A. N., and Rainbird, R. H., 1992, Nature and timing of Franklin igneous events, Canada: Implications for a Late Proterozoic mantle plume and the break-up of Laurentia: Earth and Planetary Science Letters, v. 109, n. 1-2, p. 117-131, https://doi.org/10.1016/0012-821X(92)90078-A

Hein, F. J., and McMechan, M. E., 1994, Proterozoic-Lower Cambrian strata of the western Canada sedimentary basin: Geological Atlas of the Western Canada Sedimentary Basin: Canadian Society of 
Petroleum Geologists and Alberta Research Council, Mossop, G. D., and Shetsen, I., (compliers), p. 57-67, http://ags.aer.ca/publications/chapter-6-proterozoic-and-lower-cambrian-strata

Hildebrand, R. S., 2009, Did westward subduction cause Cretaceous-Tertiary orogeny in the North American Cordillera?: Geological Society of America Special Papers, v. 457, p. 1-71, https://doi.org/ $10.1130 / 2009.2457$

Hoffman, P. F., 1991, Did the breakout of Laurentia turn Gondwanaland inside-out: Science, v. 252, n. 5011, p. 1409-1412, https://doi.org/10.1126/science.252.5011.1409

Hoffman, P. F., and Schrag, D. P., 2002, The snowball Earth hypothesis: Testing the limits of global change: Terra Nova, v. 14, n. 3, p. 129-155, https://doi.org/10.1046/j.1365-3121.2002.00408.x

Jaffey, A. H., Flynn, K. F., Glendenin, L. E., Bentley, W. C., and Essling, A. M., 1971, Precision measurements of half-lives and specific activities of ${ }^{235} \mathrm{U}$ and ${ }^{238} \mathrm{U}$ : Physical Review C, v. 4, p. 1889-1906, https://doi.org/ 10.1103/PhysRevC.4.1889

Jefferson, C. W., and Parrish, R. R., 1989, Late Proterozoic stratigraphy, U-Pb zircon ages, and rift tectonics, Mackenzie Mountains, northwestern Canada: Canadian Journal of Earth Sciences, v. 26, n. 9, p. 1784-1801, https://doi.org/10.1139/e89-151

Jerram, D., and Petford, N., 2011, The field description of igneous rocks: West Sussex, United Kingdom, John Wiley \& Sons, Geological Field Guide Series, v. 40, 256 p.

Karlstrom, K. E., Bowring, S. A., Dehler, C. M., Knoll, A. H., Porter, S. M., Des Marais, D. J., Weil, A. B., Sharp, Z. D., Geissman, J. W., Elrick, M. B., Timmons, J. M., Crossey, L. J., and Davidek, K. L., 2000, Chuar Group of the Grand Canyon: Record of breakup of Rodinia, associated change in the global carbon cycle, and ecosystem expansion by 740 Ma: Geology, v. 28, n. 7, p. 619-622, https://doi.org/10.1130/ 0091-7613(2000) 28<619:CGOTGC>2.0.CO;2

Keeley, J. A., Link, P. K., Fanning, C. M., and Schmitz, M. D., 2013, Pre-to synglacial rift-related volcanism in the Neoproterozoic (Cryogenian) Pocatello Formation, SE Idaho: New SHRIMP and CA-ID-TIMS constraints: Lithosphere, v. 5, n. 1, p. 128-150, https://doi.org/10.1130/L226.1

Kendall, B. S., Creaser, R. A., Ross, G. M., and Selby, D., 2004, Constraints on the timing of Marinoan "Snowball Earth" glaciation by $187 \mathrm{Re}-187 \mathrm{O}$ dating of a Neoproterozoic, post-glacial black shale in western Canada: Earth and Planetary Science Letters, v. 222, n. 3-4, p. 729-740, https://doi.org/ 10.1016/j.epsl.2004.04.004

Kirschvink, J. L., 1992, Late Proterozoic low-latitude global glaciation: The snowball earth, in Schopf, J. W., and Klein, C., editors, The Proterozoic Biosphere: Cambridge, Cambridge University Press, p. 51-52.

Klein, C., and Beukes, N. J., 1993, Sedimentology and geochemistry of the glaciogenic late Proterozoic Rapitan iron-formation in Canada: Economic Geology, v. 88, n. 3, p. 542-565, https://doi.org/10.2113/ gsecongeo.88.3.542

Le Heron, D. P., Cox, G., Trundley, A., and Collins, A. S., 2011, Two Cryogenian glacial successions compared: Aspects of the Sturt and Elatina sediment record of South Australia: Precambrian Research, v. 186, n. 1-4, p. 147-168, https://doi.org/10.1016/j.precamres.2011.01.014

Lescinsky, D. T., and Sisson, T. W., 1998, Ridge-forming, ice-bounded lava flows at Mount Rainier, Washington: Geology, v. 26, n. 4, p. 351-354, https://doi.org/10.1130/0091-7613(1998)026<0351: RFIBLF $>2.3 . \mathrm{CO} ; 2$

Li, Z.-X., Bogdanova, S. V., Collins, A. S., Davidson, A., De Waele, B., Ernst, R. E., Fitzsimmons, I. C. W., Fuck, R. A., Gladkochub, D. P., Jacobs, J., Karlstrom, K. E., Lu, S., Natapov, L. M., Pease, V., Pisarevsky, S. A., Thrane, K., and Vernikovsky, V., 2008, Assembly, configuration, and break-up history of Rodinia: A synthesis: Precambrian Research, v. 160, n. 1-2, p. 179-210, https://doi.org/10.1016/j. precamres.2007.04.021

Li, Z. X., Evans, D. A. D., and Halverson, G. P., 2013, Neoproterozoic glaciations in a revised global palaeogeography from the breakup of Rodinia to the assembly of Gondwanaland: Sedimentary Geology, v. 294, p. 219-232, https://doi.org/10.1016/j.sedgeo.2013.05.016

Link, P. K., Christie-Blick, N., Devlin, W. J., Elston, D. P., Horodyski, R. J., Levy, M., Miller, J. M. G., Pearson, R. C., Prave, A., Stewart, J. H., Winston, D., Wright, L. A., and Wrucke, C. T., 1993, Middle and Late Proterozoic stratified rocks of the western U.S. Cordillera, Colorado Plateau, and Basin and Range Province: Boulder, Colorado, The Geological Society of America, The Geology of North America, v. 2, p. 463-595, https://doi.org/10.1130/DNAG-GNA-C2.463

Link, P. K., Miller, J. M. G., and Christie-Blick, N., 1994, Glacial-marine facies in a continental rift environment: Neoproterozoic rocks of the western United States Cordillera, in Deynoux, M., Miller, J. M. G., Domack, E. W., Eyles, N., Fairchild, I., and Young, G. M., editors, International Geological Correlation Project 260: Earth's Glacial Record: Cambridge, United Kingdom, Cambridge University Press, p. 29-59, https://doi.org/10.1017/CBO9780511628900.003

Lister, G. S., Etheridge, M. A., and Symonds, P. A., 1986, Detachment faulting and the evolution of passive continental margins: Geology, v. 14, n. 3, p. 246-250, https://doi.org/10.1130/0091-7613(1986) 14<246: DFATEO $>2.0 . \mathrm{CO} ; 2$

Lønne, I., 1995, Sedimentary facies and depositional architecture of ice-contact glaciomarine systems: Sedimentary Geology, v. 98, n. 1-4, p. 13-43, https://doi.org/10.1016/0037-0738(95)00025-4

Lund, K., 2008, Geometry of the Neoproterozoic and Paleozoic rift margin of western Laurentia: Implications for mineral deposit settings: Geosphere, v. 4, n. 2, p. 429-444, https://doi.org/10.1130/ GES00121.1

Lund, K., Aleinikoff, J. N., Evans, K. V., and Fanning, C. M., 2003, SHRIMP U-Pb geochronology of Neoproterozoic Windermere Supergroup, central Idaho: Implications for rifting of western Laurentia and synchroneity of Sturtian glacial deposits: Geological Society of America Bulletin, v. 115, n. 3, p. 349-372, https://doi.org/10.1130/0016-7606(2003)115<0349:SUPGON>2.0.CO;2

Lund, K., Aleinikoff, J. N., Evans, K. V., duBray, E. A., Dewitt, E. H., and Unruh, D. M., 2010, SHRIMP U-Pb dating of recurrent Cryogenian and Late Cambrian-Early Ordovician alkalic magmatism in central 
Idaho: Implications for Rodinian rift tectonics: Geological Society of America Bulletin, v. 122, n. 3-4. p. 430-453, https://doi.org/10.1130/B26565.1

Macdonald, F. A., Schmitz, M. D., Crowley, J. L., Roots, C. F., Jones, D. S., Maloof, A. C., Strauss, J. V., Cohen, P. A., Johnston, D. T., and Schrag, D. P., 2010a, Calibrating the Cryogenian: Science, v. 327, n. 5970, p. 1241-1243, https://doi.org/10.1126/science.1183325

Macdonald, F. A., Strauss, J. V., Rose, C. V., Dudás, F. Ô., and Schrag, D. P., 2010b, Stratigraphy of the Port Nolloth Group of Namibia and South Africa and implications for the age of Neoproterozoic iron formations: American Journal of Science, v. 310, n. 9, p. 862-888, https://doi.org/10.2475/09.2010.05

Macdonald, F. A., Smith, E. F., Strauss, J. V., Cox, G. M., Halverson, G. P., and Roots, C. F., 2011, Neoproterozoic and early Paleozoic correlations in the western Ogilvie Mountains, Yukon, in MacFarlane, K. E., Weston, L. H., and Relf, C., editors, Yukon Exploration and Geology 2010: Yukon Geological Survey, p. 161-182

Macdonald, F. A., Prave, A. R., Petterson, R., Smith, E. F., Pruss, S. B., Oates, K., Waechter, F., Trotzuk, D. and Fallick, A. E., 2013a, The Laurentian record of Neoproterozoic glaciation, tectonism, and eukaryotic evolution in Death Valley, California: Geological Society of America Bulletin, v. 125, n. 7-8, p. 1203-1223, https://doi.org/10.1130/B30789.1

Macdonald, F. A., Strauss, J. V., Sperling, E. A., Halverson, G. P., Narbonne, G. M., Johnston, D. T., Kunzmann, M., Schrag, D. P., and Higgins, J. A., 2013b, The stratigraphic relationship between the Shuram carbon isotope excursion, the oxygenation of Neoproterozoic oceans, and the first appearance of the Ediacara biota and bilaterian trace fossils in northwestern Canada: Chemical Geology, v. 362, p. 250-272, https://doi.org/10.1016/j.chemgeo.2013.05.032

Mathews W. H., 1947, "Tuyas," flat-topped volcanoes in northern British Columbia: American Journal of Science, v. 245, n. 9, p. 560-570, https://doi.org/10.2475/ajs.245.9.560

Mattinson, J. M., 2005, Zircon U-Pb chemical abrasion ("CA-TIMS") method: Combined annealing and multi-step partial dissolution analysis for improved precision and accuracy of zircon ages: Chemical Geology, v. 220, n. 1-2, p. 47-66, https://doi.org/10.1016/j.chemgeo.2005.03.011

McDonough, M. R., and Parrish, R. R., 1991, Proterozoic gneisses of the Malton Complex, near Valemount, British Columbia: U-Pb ages and Nd isotopic signatures: Canadian Journal of Earth Sciences, v. 28, n. 8, p. 1202-1216, https://doi.org/10.1139/e91-108

McDonough, W. F., and Sun S. S., 1995, The composition of the Earth: Chemical Geology, v. 120, n. 3-4, p. 223-253, https://doi.org/10.1016/0009-2541(94)00140-4

McGarvie, D., 2009, Rhyolitic volcano-ice interactions in Iceland: Journal of Volcanology and Geothermal Research, v. 185, n. 4, p. 367-389, https://doi.org/10.1016/j.jvolgeores.2008.11.019

McLean, N. M., Condon, D. J., Schoene, B., and Bowring, S. A., 2015, Evaluating uncertainties in the calibration of isotopic reference materials and multi-element isotopic tracers (EARTHTIME Tracer Calibration Part II): Geochimica et Cosmochimica Acta, n. 164, p. 481-501, https://doi.org/10.1016/ j.gca.2015.02.040

McMechan, M. E., 2000, Vreeland Diamictites-Neoproterozoic glaciogenic slope deposits, Rocky Mountains, northeast British Columbia: Bulletin of Canadian Petroleum Geology, v. 48, n. 3, p. 246-261, https://doi.org/10.2113/48.3.246

2015, The Neoproterozoic succession of the central Rocky Mountains, Canada: Bulletin of Canadian Petroleum Geology, v. 63, n. 3, p. 243-273, https://doi.org/10.2113/gscpgbull.63.3.243

Meert, J. G., and Torsvik, T. H., 2003, The making and unmaking of a supercontinent: Rodinia revisited: Tectonophysics, v. 375, n. 1-4, p. 261-288, https://doi.org/10.1016/S0040-1951(03)00342-1

Miller, F. K., 1994, The Windermere Group and late Proterozoic tectonics in northeastern Washington and northern Idaho, Regional geology of Washington: Washington Division of Geology and Earth Resources Bulletin, v. 80, p. 1-19.

Milton, J. E., Hickey, K. A., and Gleeson, S. A., 2014, New U-Pb constraints on Gunbarrel volcanism and the break-up of Rodinia: The 775 Ma Little Dal basalts: 2014 GSA Annual Meeting in Vancouver, British Columbia.

Moores, E. M., 1991, Southwest US-East Antarctic (SWEAT) connection: A hypothesis: Geology, v. 19, n. 5, p. 425-428, https://doi.org/10.1130/0091-7613(1991)019<0425:SUSEAS>2.3.CO;2

Moynihan, D., 2014, Bedrock Geology of NTS 106B/04, Eastern Rackla Belt, in MacFarlane, K. E., Nordling, M. G., and Sack, P. J. editors, Yukon Exploration and Geology 2013: Yukon Geological Survey, p. $147-167$.

Nasdala, L., Lengauer, C. L., Hanchar, J. M., Kronz, A., Wirth, R., Blanc, P., Kennedy, A. K., and Seydoux-Guillaume, A. M., 2002, Annealing radiation damage and the recovery of cathodoluminescence: Chemical Geology, v. 191, n. 1-3, p. 121-140, https://doi.org/10.1016/S0009-2541(02)00152-3

Passchier, S., O’Brien, P. E., Damuth, J. E., Januszczack, N., Handwerger, D. A., and Whitehead, J. M., 2003, Pliocene- Pleistocene glaciomarine sedimentation in eastern Prydz Bay and development of the Prydz trough-mouth fan, ODP Sites 1166 and 1167, East Antarctica: Marine Geology, v. 199, n. 3-4, p. 179-305, https://doi.org/10.1016/S0025-3227(03)00160-9

Pigage, L. C., 2006, Stratigraphy summary for southeast Yukon (95D/8 and 95C/5), in Emond, D. S., Bradshaw, G. D., Lewis, L. L., and Weston, L. H., editors, Yukon Exploration and Geology 2005: Yukon Geological Survey, p. 267-285.

2009, Bedrock geology of NTS 95C/5 (Pool Creek) and NTS 95D/8 map sheets, southeast Yukon: Yukon Geological Survey Bulletin 16, p. 1-150.

Pigage, L. C., and MacNaughton, R. B., 2004, Reconnaissance geology of northern Toobally Lake (95D/8), southeast Yukon, in Emond, D. S., and Lewis, L. L., editors, Yukon Exploration and Geology 2003: Yukon Geological Survey, p. 199-219.

Pigage, L. C., and Mortensen, J. K., 2004, Superimposed Neoproterozoic and early Tertiary alkaline 
magmatism in the La Biche River area, southeast Yukon Territory: Bulletin of Canadian Petroleum Geology, v. 52, n. 4, p. 325-342, https://doi.org/10.2113/52.4.325

Pisarevsky, S. A., Wingate, M. T., Powell, C. M., Johnson, S., and Evans, D. A. D., 2003, Models of Rodinia assembly and fragmentation: Geological Society, London, Special Publications, v. 206, n. 1, p. 35-55, https://doi.org/10.1144/GSL.SP.2003.206.01.04

Porter, S. M., and Knoll, A. H., 2000, Testate amoebae in the Neoproterozoic Era: Evidence from vase-shaped microfossils in the Chuar Group, Grand Canyon: Paleobiology, v. 26, n. 3, p. 360-385, https://doi.org/ 10.1666/0094-8373(2000) 026<0360:TAITNE $>2.0$.CO;2

Postma, G., Nemec, W., and Kleinspehn, K. L., 1988, Large floating clasts in turbidites: A mechanism for their emplacement: Sedimentary Geology, v. 58, n. 1, p. 47-61, https://doi.org/10.1016/00370738(88)90005-X

Prave, A. R., 1999, Two diamictites, two cap carbonates, two $\delta^{13} \mathrm{C}$ excursions, two rifts: The Neoproterozoic Kingston Peak Formation, Death Valley, California: Geology, v. 27, n. 4, p. 339-342, https://doi.org/ 10.1130/0091-7613(1999)027<0339:TDTCCT > 2.3.CO;2

Prave, A. R., Condon, D. J., Hoffmann, K. H., Tapster, S. and Fallick, A. E., 2016, Duration and nature of the end-Cryogenian (Marinoan) glaciation: Geology, v. 44, n. 8, p. 631-634, https://doi.org/10.1130/ G38089.1

Rainbird, R. H., Cawood, P., and Gehrels, G., 2012, The great Grenvillian sedimentation episode: Record of supercontinent Rodinia's assembly, in Busby, C., and Azor, A., editors, Tectonics of Sedimentary Basins: Recent Advances: Chichester, United Kingdom, Wiley, chapter 29, https://doi.org/10.1002/ 9781444347166.ch29

Rooney, A. D., Macdonald, F. A., Strauss, J. V., Dudás, F. Ö., Hallmann, C., and Selby, D., 2014, Re-Os geochronology and coupled Os-Sr isotope constraints on the Sturtian snowball Earth: Proceedings of the National Academy of Sciences of the United States of America, v. 111, n. 1, p. 51-56, https://doi.org/ 10.1073 /pnas. 1317266110

Rooney, A. D., Strauss, J. V., Brandon, A. D., and Macdonald, F. A., 2015, A Cryogenian chronology: Two long-lasting, synchronous Neoproterozoic glaciations: Geology, v. 43, n. 5, p. 459-462, https://doi.org/ $10.1130 / \mathrm{G} 36511.1$

Ross, G. M., 1991, Tectonic setting of the Windermere Supergroup revisited: Geology, v. 19, n. 11, p. 1125-1128, https:/ / doi.org/10.1130/0091-7613(1991)019<1125:TSOTWS >2.3.CO;2

Ross, G. M., Bloch, J. D., and Krouse, H. R., 1995, Neoproterozoic strata of the southern Canadian Cordillera and the isotopic evolution of seawater sulfate: Precambrian Research, v. 73, n. 1-4, p. 71-99, https://doi.org/10.1016/0301-9268(94)00072-Y

Schmitz, M. D., and Davydov, V. I., 2012, Quantitative radiometric and biostratigraphic calibration of the Pennsylvanian - Early Permian (Cisuralian) time scale and pan-Euramerican chronostratigraphic correlation: Geological Society of America Bulletin, v. 124, n. 3-4, p. 549-577, https:/ /doi.org/10.1130/ B30385.1

Schmitz, M. D., and Schoene, B., 2007, Derivation of isotope ratios, errors, and error correlations for U-Pb geochronology using ${ }^{205} \mathrm{~Pb}^{235} \mathrm{U}-\left({ }^{233} \mathrm{U}\right)$-spiked isotope dilution thermal ionization mass spectrometric data: Geochemistry, Geophysics, Geosystems, v. 8, n. 8, https://doi.org/10.1029/2006GC001492

Schoene, B., 2014, 4.10-U-Th-Pb Geochronology: Oxford, England, Elsevier, Treatise on Geochemistry, Second Edition, p. 341-378, https://doi.org/10.1016/B978-0-08-095975-7.00310-7

Sears, J. W., and Price, R. A., 1978, The Siberian connection: A case for Precambrian separation of the North American and Siberian cratons: Geology, v. 6, n. 5, p. 267-270, https://doi.org/10.1130/00917613(1978) $6<267:$ TSCACF $>2.0 . \mathrm{CO} ; 2$

2003, Tightening the Siberian connection to western Laurentia: Geological Society of America Bulletin, v. 115, n. 8, p. 943-953, https://doi.org/10.1130/B25229.1

Skilling, I. P., 2009, Subglacial to emergent basaltic volcanism at Hlöðufell, south-west Iceland: A history of ice-confinement: Journal of Volcanology and Geothermal Research, v. 185, n. 4, p. 276-289, https:// doi.org/10.1016/j.jvolgeores.2009.05.023

Slind, O. L., and Perkins, G. D., 1966, Lower Paleozoic and Proterozoic sediments of the Rocky Mountains between Jasper, Alberta and Pine River, British Columbia: Bulletin of Canadian Petroleum Geology, v. 14 , n. 4, p. 442-468.

Smellie, J. L., and Hole, M. J., 1997, Products and processes in Pliocene-Recent, subaqueous to emergent volcanism in the Antarctic Peninsula: Examples of englacial Surtseyan volcano construction: Bulletin of Volcanology, v. 58, n. 8, p. 628-646, https://doi.org/10.1007/s004450050167

Smellie, J. L., and Skilling, I. P., 1994, Products of subglacial volcanic eruptions under different ice thicknesses: Two examples from Antarctica: Sedimentary Geology, v. 91, n. 1-4, p. 115-129, https:// doi.org/10.1016/0037-0738(94)90125-2

Smith, E. F., MacDonald, F. A., Crowley, J. L., Hodgin, E. B., and Schrag, D. P., 2016, Tectonostratigraphic evolution of the $c$. 780-730 Ma Beck Spring Dolomite: Basin Formation in the core of Rodinia: Geological Society, London, Special Publications, v. 424, p. 213-239, https://doi.org/10.1144/SP424.6

Smith, M. D., Arnaud, E., Arnott, R. W. C., and Ross, G. M., 2011, The record of Neoproterozoic glaciations in the Windermere Supergroup, southern Canadian Cordillera: Geological Society, London, Memoirs, v. 36, p. 413-424, https://doi.org/10.1144/M36.37

Smith, M. D., Arnott, R. W. C., and Ross, G. M., 2014, Physical and geochemical controls on sedimentation along an ancient continental margin: The deep-marine Old Fort Point Formation (Ediacaran), southern Canadian Cordillera: Bulletin of Canadian Petroleum Geology, v. 62, n. 1, p. 14-36, https://doi.org/10.2113/gscpgbull.62.1.14

Spence, G. H., Le Heron, D. P., and Fairchild, I. J., 2016, Sedimentological perspectives on climatic, atmospheric and environmental change in the Neoproterozoic Era: Sedimentology, v. 63, n. 2, p. 253-306, https://doi.org/10.1111/sed.12261 
Stacey, J. S., and Kramers, J. D., 1975, Approximation of terrestrial lead isotope evolution by a two-stage model: Earth and Planetary Science Letters, v. 26, n. 2, p. 207-221, https://doi.org/10.1016/0012$821 \mathrm{X}(75) 90088-6$

Stewart, J. N., 1972, Initial deposits in the Cordilleran geosyncline: Evidence for a late Precambrian $(<850$ m.y.) continental separation: Geological Society of America Bulletin, v. 83, n. 5, p. 1345-1360, https://doi.org/10.1130/0016-7606(1972)83[1345:IDITCG]2.0.CO;2

Strauss, J. V., Rooney, A. D., Macdonald, F. A., Brandon, A. D., and Knoll, A. H., 2014a, 740 Ma vase-shaped microfossils from Yukon, Canada: Implications for Neoproterozoic chronology and biostratigraphy: Geology, v. 42, n. 8, p. 659-662, https://doi.org/10.1130/G35736.1

Strauss, J. V., Roots, C. F., Macdonald, F. A., Halverson, G. P., Eyster, A. E., and Colpron, M., 2014b, Geological map of the Coal Creek Inlier, Ogilvie Mountains (NTS 116B/10-15 and 116C/9,16): Yukon Geological Survey, Open File 2014-15, 1:100,000 scale.

Strauss, J. V., Macdonald, F. A., Halverson, G. P., Tosca, N. J., Schrag, D. P., and Knoll, A. H., 2015 Stratigraphic evolution of the Neoproterozoic Callison Lake Formation: Linking the break-up of Rodinia to the Islay carbon isotope excursion: American Journal of Science, v. 315, n. 10, p. 881-944, https://doi.org/10.2475/10.2015.01

Sun, S. S., and McDonough, W. F., 1989, Chemical and isotopic systematics of oceanic basalts: Implications for mantle composition and processes: Geological Society, London, Special Publications, v. 42, p. 313-345, https://doi.org/10.1144/GSL.SP.1989.042.01.19

Thomas, G. S. P., and Connell, R. J., 1985, Iceberg drop, dump and grounding structures from Pleistocene glacio-lacustrine sediments, Scotland: Journal of Sedimentary Petrology, v. 55, n. 2, p. 243-249, https://doi.org/10.1306/212F8689-2B24-11D7-8648000102C1865D

Tuffen, H., Gilbert, J., and McGarvie, D., 2001, Products of an effusive subglacial rhyolite eruption: Bláhnúkur, Torfajökull, Iceland: Bulletin of Volcanology, v. 63, n. 2-3, p. 179-190, https://doi.org/ $10.1007 / \mathrm{s} 004450100134$

Wallmann, K., 2001, Controls on the Cretaceous and Cenozoic evolution of seawater composition, atmospheric $\mathrm{CO}_{2}$ and climate: Geochimica et Cosmochimica Acta, v. 65, n. 18, p. 3005-3025, https://doi.org/ 10.1016/S0016-7037(01)00638-X

Wang, D., and Hesse, R., 1996, Continental slope sedimentation adjacent to an ice-margin. II. Glaciomarine depositional facies on Labrador Slope and glacial cycles: Marine Geology, v. 135, n. 1-4, p. 65-96, https://doi.org/10.1016/S0025-3227(96)00012-6

Warren, M. J., ms, 1997, Tectonic significance of stratigraphic and structural contrasts between the Purcell anticlinorium and the Kootenay arc, Duncan Lake area, British Columbia: Kingston, Ontario, Canada, Queen's University, Ph. D. thesis, $316 \mathrm{p}$.

Wendt, I., and Carl, C., 1991, The statistical distribution of the mean squared weighted deviation: Chemical Geology: Isotope Geoscience Section, v. 86, n. 4, p. 275-285, https://doi.org/10.1016/01689622(91) 90010-T

Werner, R., Schmincke, H. U., and Sigvaldason, G., 1996, A new model for the evolution of table mountains: Volcanological and petrological evidence from Herdubreid and Herdubreidartögl volcanoes (Iceland): Geolische Rundschau, v. 85, p. 390-397, https://doi.org/10.1007/BF02422244

Wernicke, B., 1985, Uniform-sense normal simple shear of the continental lithosphere: Canadian Journal of Earth Sciences, v. 22, n. 1, p. 108-125, https://doi.org/10.1139/e85-009

Wheeler, J. O., and McFeely, P., 1991, Tectonic assemblage map of the Canadian Cordillera and adjacent parts of the United States of America: Geological Survey of Canada, Map 1712A, scale 1:2,000,000.

Wood, D. A., 1980, The application of a Th-Hf-Ta diagram to problems of tectonomagmatic classification and to establishing the nature of crustal contamination of basaltic lavas of the British Tertiary Volcanic Province: Earth and Planetary Science Letters, v. 50, n. 1, p. 11-30, https://doi.org/10.1016/0012821X (80)90116-8

Yang, J., Cawood, P. A., Du, Y., Huang, H., Huang, H., and Tao, P., 2012, Large Igneous Province and magmatic arc sourced Permian-Triassic volcanogenic sediments in China: Sedimentary Geology, v. 261-262, p. 120-131, https://doi.org/10.1016/j.sedgeo.2012.03.018

Yeo, G. M., 1981, The Late Proterozoic Rapitan glaciation in the northern Cordillera, in Campbell, F. H. A. editor, Proterozoic basins of Canada: Geological Survey of Canada Paper 81-10, p. 25-46, https://doi.org/ $10.4095 / 109383$

Yonkee, W. A., Dehler, C. D., Link, P. K., Balgord, E. A., Keeley, J. A., Hayes, D. S., Wells, M. L., Fanning, C. M., and Johnston, S. M., 2014, Tectono-stratigraphic framework of Neoproterozoic to Cambrian strata, west-central US: Protracted rifting, glaciation, and evolution of the North American Cordilleran margin: Earth-Science Reviews, v. 136, p.59-95, https://doi.org/10.1016/j.earscirev.2014.05.004

Young, G. M., 1976, Iron-formation and glaciogenic rocks of the Rapitan Group, Northwest Territories, Canada: Precambrian Research, v. 3, n. 2, p. 137-158, https://doi.org/10.1016/0301-9268(76)90030-9

Zhang, S., Jiang, G., and Han, Y., 2008, The age of the Nantuo Formation and Nantuo glaciation in South China: Terra Nova, v. 20, n. 4, p. 289-294, https://doi.org/10.1111/j.1365-3121.2008.00819.x 